\title{
Leksik Ivančićeva zbornika
}

\begin{abstract}
Predmet je ovoga rada leksik Ivančićeva zbornika, hrvatskoglagoljskoga rukopisa različitoga religiozno-moralnog sadržaja iz 14. - 15. stoljeća, koji je ime dobio po franjevcu trećorecu glagoljašu Stjepanu Ivančiću, koji ga je pronašao u trećoredskom samostanu sv. Marije na Glavotoku. Hrvatskoglagoljski su zbornici kodeksi koji predstavljaju neprekinutu crtu hrvatskoga književnojezičnoga kontinuiteta jer su pisani mješavinom crkvenoslavenskoga i hrvatskoga jezika. Stoga je svaki od njih potrebno detaljno opisati na svim jezičnim razinama. Osnovna je karakteristika Ivančićeva zbornika jezična šarolikost, što posebice dolazi do izražaja na leksičkoj razini. Neki su dijelovi pisani arhaičnijim jezikom te sadrže više crkvenoslavenskih leksema, a drugi su pomlađeni kroatizmima, čakavskim te, nešto manje, kajkavskim leksemima. U radu se nastoji odgovoriti na pitanje kakav je omjer crkvenoslavenskih i hrvatskih leksema u pojedinim tekstovima Ivančićeva zbornika. Posebice se obraća pozornost na unošenje kajkavizama, tj. jesu li oni u svim dijelovima rukopisa ravnomjerno raspoređeni.
\end{abstract}

\section{Franjevački utjecaji u hrvatskoglagoljskim rukopisima}

Osim nekih biskupija, crkvenoslavenskim su se liturgijskim jezikom na hrvatskom području služili pojedini benediktinski i pavlinski samostani te franjevačka trećoredska provincija. „No, postojanje franjevačkog elementa u hrvatskoglagoljskim liturgijskim knjigama ni u kom slučaju ne smijemo isključivo vezati uz potrebe i djelovanje trećoredaca glagoljaša. Jedan je tome razlog što danas premalo znamo o trećoredskoj zajednici prije 1439. (...) Zatim, iz samih knjiga dolazimo do uvjerenja da je prisutan utjecaj svih redova u oblikovanju knjiga, pa uz franjevački elemenat otkrivamo također benediktinske i pavlinske utjecaje. Ni po podrijetlu, ni po namjeni, ni po sadržaju nije moguće nijedan glagoljski kodeks proglasiti naprosto benediktinskim, pavlinskim ili franjevačkim, jer sve utjecaje, više ili manje naglašeno, nalazimo u svim, bar značajnijim kodeksima“. ${ }^{1}$ Među glagoljskim je kodeksima bilo mnogo raznolikosti. U svakom se ogleda utjecaj sredine za koju je pisan. Premda kodekse nije moguće podijeliti po pripadnosti redovima ili biskupijama ${ }^{2}$, ipak ih je u toj šarolikosti lako uočiti. Tako npr. zapažamo

TANDARIĆ 1993: 36-37.

2 Isto: 37. 
franjevačke elemente u II. novljanskom brevijaru, koji je pisan 1495. za pavlinski samostan sv. Marije u Novom Vinodolskom, s tipičnim pavlinskim svetkovinama, poput sv. Pavla Pustinjaka s oktavom ili pak sv. Augustina s oktavom. Naime, u njemu, kao u nijednom drugome, ima toliko franjevačkih tekstova ${ }^{3}$, primjerice: Prnesenie s(veta)go Brnardina is(povêdbnika), Prnesenie s(veta)go Frančis'ka is (povêdınika), An toniê reda malihb bratb is (povêdbnika) itd. ${ }^{4}$ Blagdan se Rana sv. Franje, među kalendarima i sanktoralima hrvatskoglagoljskih misala i brevijara, nalazi jedino u II. novljanskom brevijaru.

U Berlinskom misalu iz 1402. nalazimo nedvojbeno benediktinske tragove, a kasnije, kad je misal dospio kod trećoredaca, u nj je unesen franjevački obrazac mise u čast Marijina Pohođenja. ${ }^{5}$ Osim toga, u tom se rukopisu nalazi bilješka: a to su knige fra Petra fratra tretoga reda sv(eta)go Frančiska ki staše u sv(eta) go Kr(i)$\check{z} a{ }^{6}{ }^{6}$ Odraz je franjevačke prisutnosti u hrvatskoglagoljskim kodeksima, primjerice u 5. i 6. vatikanskom brevijaru, također i rana prisutnost svetaca zaštitnika Trećega reda, poput sv. Franje, sv. Ljudevita, sv. Elizabete, sv. Eleazara ispovjednika, sv. Ivona itd. ${ }^{7}$ Prema istraživanjima Marka Japundžića, dva hrvatskoglagoljska rukopisa - vatikanski Illirico 6. i vatikanski Illirico 19. - franjevački su brevijari jer imaju vlastite službe franjevačkih svetaca. ${ }^{8}$

U kalendarima hrvatskoglagoljskih liturgijskih kodeksa nalazimo sljedeće franjevačke blagdane: Prijenos moći sv. Franje, sv. Antun, sv. Klara, sv. Ljudevit biskup, sv. Ljudevit kralj, sv. Franjo, sv. Elizabeta itd. Njih nalazimo i u drugim rukopisima, ali u franjevačkim su istaknutiji, odnosno označeni crveno. Katkad nose oznaku duplex, a ponekad je to jasno označeno u rubrici, npr. u VIII. vatikanskom misalu ili Baromićevu brevijaru: duplex svome redu. Kalendari se i sanktorali katkad ne slažu, tj. u kalendaru nalazimo one blagdane kojih nema u sanktoralu i obrnuto. Primjerice, u IV. se vatikanskom misalu u kalendaru ne spominje Prijenos moći sv. Franje, dok se taj blagdan nalazi u propriju svetaca, što je iznimno važno za franjevačko podrijetlo toga misala. ${ }^{9}$ Prema izgledu rukopisa, formatu, slovima i opremi, Vinodolski je brevijar (Kukuljevićev) iz 1485. pisan za neki kor, a sudeći prema sanktoralu, najvjerojatnije franjevački. ${ }^{10}$ Među tiskanim je hrvatskoglagoljskim kodeksima franjevački i to trećoredski utjecaj zamijećen u

\footnotetext{
Na istome mjestu.

4 PANTELIĆ 1977: 25.

5 Isti 1964: 24.

6 Na istome mjestu.

7 RUNJE 2012: 68.

8 JAPUNDŽIĆ 1955: 187-188.

9 TANDARIĆ 1993: 38.

10 ŠTEFANIĆ 1969: 148.
} 
Baromićevu brevijaru iz $1493 .{ }^{11}$ On se razlikuje od starijih glagoljskih rukopisnih brevijara jer u kalendaru ima nove franjevačke blagdane i blagdane koji se slave u Zadru, a u sanktoralu nove franjevačke službe. ${ }^{12}$

Franjevačkomu se utjecaju može pripisati unošenje sekvencije Dies irae, potresne pjesme o sudnjem danu, u misale. Iako je taj tekst vrlo star, u latinskim se misalima razmjerno kasno pojavljuje, dok ga glagoljski misali svi imaju. ${ }^{13}$ I širenje kulta sv. Šimuna treba pripisati franjevačkoj trećoredskoj zajednici, premda nije riječ o franjevačkom svecu, a prva je zabilježila i rimovanu mrtvačku sekvenciju Sudac gnêvan hoće priti, koja se već prije iz usmene tradicije proširila po hrvatskom području. ${ }^{14}$

Premda je franjevački element na različite načine prisutan u hrvatskoglagoljskim kodeksima, on nije uvijek tako jednoznačan, niti posvuda jednako proveden da bi se neki kodeks mogao proglasiti franjevačkim. „Sagledan u cjelini, franjevački je utjecaj mnogo širi negoli bi se mogao očekivati, jer po onome koliko nam je danas poznat, prelazi potrebe franjevačke trećoredske zajednice. Nalazimo ga naime $u$ kodeksima namijenjenima svjetovnom kleru i drugim redovničkim zajednicama“.15

Ivančićev zbornik hrvatskoglagoljski je rukopis, koji je zasigurno pisan za franjevce trećorece jer se u njemu nalazi i Pismo pokornicima sv. Franje Asiškoga. ${ }^{16}$ Na temelju molitava kod stola, što je ujedno najstariji dio zbornika (f. 172 - 182), Ivan Milčetić prvi je zaključio da su kodeks pisali redovnici i to franjevci trećoreci. ${ }^{17}$ Petar Runje slaže se s tim mišljenjem te navodi kako je ,,sasvim uvjerljivo da je zbornik franjevačkoga nadahnuća“ jer npr. „u molitvi koja se pripisuje sv. Klementu papi kaže (se): 'Diva pred porodom. diva v porode. diva po porode'“', a to su „riječi i sadržaj franjevačke teologije“. ${ }^{18} \mathrm{Na}$ koncu pretpostavlja da je zbornik prepisan u drugoj polovini 14. stoljeća u Zadru, gdje se nalazilo nekoliko trećoredskih samostana..$^{19}$ I Josip Leonard Tandarić je, proučavajući ritualne tekstove, zaključio da ovaj zbornik pripada trećorecima glagoljašima: „Redovničkih običaja i obreda kojima su se služili franjevački trećoreci ima brojčano znatno više, budući da su se oni u liturgiji služili isključivo staroslavenskim jezikom“". ${ }^{20}$

\footnotetext{
RUNJE 2008: 105-106.

GRABAR 1984: 180.

PANTELIĆ 1976: 246.

4 Isto: 240.

15 TANDARIĆ 1993: 39-40.

16 RUNJE 2012: 165-167.

17 MILČETIĆ 1890: 39-153.

18 RUNJE 2012: 167.

19 Na istome mjestu.

20 TANDARIĆ 1980: 28.
} 
Posljednjih stotinjak godina rukopis se čuva u Arhivu Provincijalata franjevaca trećoredaca na Ksaveru u Zagrebu, a na samom kodeksu zapisana su imena nekih trećoredaca koji su živjeli tijekom 17. stoljeća.

\section{Ivančićev zbornik (CIvan)}

Ivančićev zbornik (dalje CIvan) hrvatskoglagoljski je rukopis raznovrsnoga religiozno moralnoga sadržaja, a svoje je ime dobio po Stjepanu Ivančiću (1852. - 1925.), franjevcu trećorecu glagoljašu, koji ga je pronašao u svom samostanu sv. Marije na Glavotoku na otoku Krku. Ne zna se tko ga je napisao, no razlika u pismu, tinti i pergamentu ukazuje na najmanje dvojicu, a možda i trojicu pisara. O godini nastanka nema pouzdanih podataka, osim na f. 180r gdje se navodi 1395. Međutim, taj se podatak odnosi samo na zadnjih devet listova (f. $172-181$ ), tj. na odlomak koji je pisala druga ruka, a različita je i koža i crnilo. ${ }^{21}$ „Konačno i partija f. 172 - 181, datirana 1395., ne pokazuje paleografski ništa stariji stadij pisma, premda se ruka kao takva odvaja, a jezik joj je znatno mlađi i narodniji nego u poslanicama o sv. Jeronimu". ${ }^{22}$ Milčetić je utvrdio da je prvi dio ili iz 14. ili s početka 15. stoljeća. ${ }^{23}$ Takvu nam dataciju dopuštaju i jezični podaci. Do sličnoga je zaključka došao i Vjekoslav Štefanić, proučavajući dvije poslanice sv. Jeronima u istom zborniku: tekst nije nastao ranije od početka 15 . ni kasnije od sredine 15. stoljeća. ${ }^{24}$

Ivančićev zbornik kodeks je manjega formata $(13 \times 19 \mathrm{~cm})$ i ima ukupno 181 pergamentni list. Milčetić je okarakterizirao pismo kao uncijalnu kurzivu, dok ga je Štefanić nazvao poluustavnim pismom, koje se rabilo u neliturgijskim knjigama s konca 14. do kraja 15. stoljeća. ${ }^{25}$ Zbornik sadrži različite tekstove: Traktat o sedam smrtnih grijeha, Mirakule Blažene djevice Marije, Mirakule Marije Magdalene, Pavlovu poslanicu o ljubavi, Pismo sv. Franje, Apokrifne poslanice o sv. Jeronimu, Blagoslov stola itd. Najveći dio zbornika, više od trećine, zauzima Traktat o sedam smrtnih grijeha (f. $1^{\mathrm{r}}-$ f. $64^{\mathrm{v}}$ ). Ta je moralno asketska rasprava ovdje očuvana u cijelosti i jedna je od najvećih te vrste u hrvatskoglagoljskoj književnosti. Izvornik je toga djela tzv. Somme le Roi, priručnik moralnih uputa koje je 1279./1280., na zahtjev kralja Filipa Hrabrog, sastavio francuski dominikanac fra Lovrenc iz Orleansa (Laurentius Aurelianensis). Autor je bio inspiriran ranijim tekstovima o porocima i vrlinama, a djelo je prevođeno na mnoge jezike i bilo je poznato širom

\footnotetext{
21 ŠTEFANIĆ 1964: 108.

22 Isto: 109.

23 MILČETIĆ 1890: 39-153.

24 ŠTEFANIĆ 1964: 99-161.

25 Isto: 109.
} 
svijeta. Petar Kolendić ustanovio je da je predložak ovoga teksta bio talijanski, no nije ga mogao točno identificirati. ${ }^{26}$ „Taj je popularni srednjovjekovni spis (...) svojim jednostavnim no vrlo sugestivnim, nerijetko duhovitim, pričanjem te metaforikom i slikama iz života bliskim pučkom shvaćanju, bio očito omiljela i široko rasprostranjena lektira glagoljaških propovjednika". ${ }^{27}$ Rasprava se o svakom od smrtnih grijeha uvodi riječima iz Ivanove Apokalipse. Prema broju se smrtnih grijeha dijeli na sedam glava, a svaki se od njih još dijeli na mnoge rasohe. U Ivančićevu se zborniku nalazi i najveća glagoljska zbirka Marijinih mirakula.

\section{Jezik hrvatskoglagoljskih zbornika}

Hrvatskoglagoljski su neliturgijski rukopisi ili zbornici uglavnom nastajali tijekom 15. i 16. stoljeća, kao amalgam hrvatskoga crkvenoslavenskoga i živoga hrvatskoga jezika. „Glagoljaški pokušaji da se oblikuje hibridni književni jezik sastavljen ne samo od staroslavenskih i čakavskih nego i od kajkavskih elemenata zasvjedočeni su u glagoljičnom korpusu još od 14. stoljeća, a iz 15. stoljeća poznati su nam brojni pokušaji, i u beletrističkim i u pravnim tekstovima, u kojima je udio staroslavenskih elemenata zanemariv pa se može govoriti o čakavsko-kajkavskoj inačici hrvatskoga književnoga jezika“". ${ }^{28} \mathrm{Na}$ taj je način u hrvatskoglagoljskim zborničkim tekstovima izgrađivan hrvatski književni jezik. Jezična neujednačenost može biti uzrokovana različitim predlošcima, ali i različitim sadržajima, pa su biblijski tekstovi pisani arhaičnijim, a nebiblijski mlađim jezikom. Jezična šarolikost proizlazi iz različite namjene, kao i iz piščeve svijesti o književnom jeziku. Također, razni su dijelovi knjiga ponekad uvezani u jednu knjigu. Pri jezičnoj raščlambi to svakako treba imati u vidu, što znači da bi svaki tekst nekoga kodeksa trebalo zasebno opisati na svim jezičnim razinama.

Osnovna karakteristika Ivančićeva zbornika, što su uočili mnogi paleoslavisti, jezična je šarolikost. Primjerice, Milčetić navodi da je jezik toga zbornika prilično neujednačen, „sad više narodni, sad više staroslavenski“. Isto je primijetio i Štefanić, proučavajući poslanice sv. Jeronima: „Prije svega moramo konstatirati da je jezik ovih poslanica ustvari umjetan jezik koji se nije nikad i nigdje govorio. To je hibridan jezik koji se sastoji od tradicionalnog crkvenoslavenskog jezika u nedosljednoj mješavini s elementima živoga narodnog jezika“. ${ }^{29}$ Poslanice sv. Jeronima, u odnosu na druge dijelove zbornika, pisane su arhaičnijim jezikom: „(...) jer je pisar nastojao, koliko je znao pisati jezikom glagoljskih liturgijskih

\footnotetext{
26 KOLENDIĆ 1935: 396-400.

27 HERCIGONJA 1975: 114.

28 DAMJANOVIĆ 2011: 313.

29 ŠTEFANIĆ 1964: 118.
} 
knjiga, ali ujedno nije znao isključiti prodiranje živog narodnog jezika u jedan tekst koji se nije mogao dovoljno nasloniti na stare biblijske i ritualne jezične formule i leksik. Odatle mješavina crkvenog i narodnog elementa".${ }^{30} \mathrm{~S}$ obzirom na ostvaraj jata, Štefanić smatra da CIvan „(...) ide u tip govora koji stoji nešto sjevernije od sjevernodalmatinskih pisaca XV-og stoljeća-Zadarskog lekcionara, Bernardinova lekcionara, Žića otaca i glagoljskih isprava zadarskog kraja, a primiče se gotovo posve tipu novljanskog govora kakav je u novljanskim ispravama XIV-XV-og stoljeća i u glagoljskom Blagdanaru popa Filipa iz 1506. godine“. 31

Nadalje, za ovaj je kodeks karakterističan nastavak -ov kod imenica ž. r. u instrumentalu jednine, npr.: volevb $\left(14^{\mathrm{r}}, 86^{\mathrm{v}}, 112^{\mathrm{v}}\right)^{32}$, moĉevb $\left(14^{\mathrm{v}}\right)$, pokorovb $\left(15^{\mathrm{v}}\right)$, silovb $\left(27^{\mathrm{r}}\right)$, svoimb blizikovb $\left(39^{\mathrm{v}}\right)$, s' kolikovb velikovb mukovb $\left(67^{\mathrm{r}}\right)$, tugovb $\left(67^{\mathrm{r}}\right)$, s kolikovb mukovb (68 $)$, svoevb ljub'vovb $\left(77^{\mathrm{v}}\right)$, uzdovb $\left(77^{\mathrm{v}}\right)$, sa silovb (123'), vsakov'dikov' (155'), teš 'kov' mazdov' $\left(174^{v}\right)$ i kod zamjenica i pridjeva: sobovb $\left(3^{\mathrm{r}}, 16^{\mathrm{r}}, 66^{\mathrm{r}}, 76^{\mathrm{r}}, 77^{\mathrm{v}}, 78^{\mathrm{r}}, 86^{\mathrm{v}}, 108^{\mathrm{v}}\right)$, svoevb $\left(14^{\mathrm{r}}, 14^{\mathrm{v}}, 27^{\mathrm{r}}, 39^{\mathrm{v}}, 77^{\mathrm{v}}\right)$, pod' sobovb $\left(77^{\mathrm{v}}, 123^{\mathrm{r}}\right)$, s'moev $\left(123^{\mathrm{r}}\right)$, vsevb moevb $\left(123^{\mathrm{v}}\right)$, velikovb $\left(124^{\mathrm{r}}\right)$, sb velikovb $\left(125^{\mathrm{v}}\right)$, za m'novb $\left(128^{\mathrm{r}}\right)$. Potvrđen je i u nekim drugim starijim spomenicima: u Šibenskoj molitvi iz 14. stoljeća, u Žićima otaca iz 15. stoljeća, u Kolunićevu zborniku (Traktatu o sedam smrtnih grijeha) iz 1486., u glagoljskim ispravama zadarskoga kraja iz 15. stoljeća itd. Slični su primjeri i u Berlinskom misalu kod zamjenica s'tobovb i imenica ž. r. ženov, voljev, rukov itd. ${ }^{33}$ Milčetić je zabilježio ovaj nastavak na otocima Silbi i Olibu, a ,naročito po toj crti stavljao je prof. Stj. Ivšić i Žića otaca i Ivančićev zbornik u zadarsku okolinu“. ${ }^{34}$

Dok neke jezične crte taj tekst stavljaju u krug zadarskih jezičnih spomenika (npr. -ov), druge ga pomiču sjevernije. Prema Akademijinu rječniku, leksem gorupno, koji se pojavljuje u CIvan (164v), kajkavizam je potvrđen samo u Dubašnici na Krku. ${ }^{35}$ „Bilo kako mu drago, sigurno je jedno, a to je da su mnoge crte našeg spomenika zajedničke i zadarskom krugu, ali možda još više tipu novljanskog govora kako je potvrđen u glagoljskim spomenicima XV stoljeća, naročito u Blagdanaru iz 1506. A ne smijemo zanemariti činjenicu da je to u stvari više-manje govor Krbave i Like iz predturskog vremena potvrđen u pojedinim glagoljskim ispravama kao i u kodeksima XIV i XV stoljeća kakvi su npr. Novakov misal iz 1368., Bartolov (Berlinski) misal iz 1402., Kolunićev zbornik iz 1486. i drugi““. ${ }^{36}$

\footnotetext{
30 Isto: $109-110$.

31 Isto: $119-120$.

32 Primjere navodim prema transliteraciji Ivana Kosića, iz njegove doktorske disertacije obranjene 2010.

33 PANTELIĆ 1964: 29.

34 ŠTEFANIĆ 1964: 120

35 ARj III: 296.

36 ŠTEFANIĆ 1964: 122.
} 
Anica Nazor, proučavajući pojedine dijelove Ivančićeva zbornika, zaključila je sljedeće: „Jezična analiza Ivančićeva zbornika pokazuje da se taj spomenik cijelim svojim opsegom ne može vezati za crkvenoslavenski jezik, jer se neki dijelovi (Traktat o sedam smrtnih grêha, Ishod, Ispovêd) gotovo u potpunosti, a neki u većem dijelu svojih odlika (Kontemplacion, Riči života spaseniê, Tlkovanie ot ljubve, tumačenje mise, Riči ot nauka svetihb otacb, pitanja i odgovori i Blagoslov stola, pa i Čudesa Dêve Marie) naslanjaju na živi govor. Tek trećina Ivančićeva zbornika obuhvaća priloge koji čuvaju crkvenoslavenske jezične crte (dvije poslanice o sv. Jeronimu, Marije Magdalene mirakuli, molitve: sv. Augustina, sv. Marije, sv. Bogorodice od 7 radosti, blaženoga Bêde, sv. Tome, Klimenta pape, blaženoga Bernarda) “. ${ }^{37}$ Međutim, Ivanka Petrović, istražujući Bogorodičina čudesa u Ivančićevu zborniku, zaključila je da jezik toga dijela pruža ,sliku prožimanja crkvenoslavenskih i mlađih, narodnih živih elemenata. (...) Naš tekst ima još mnogo osobina hrvatskog tipa crkvenoslavenskog jezika, osobito u morfologiji i sintaksi. Ali po glasovnim osobinama, napose pak po leksiku, možemo ga već s pravom ubrojiti među tekstove pisane narodnim jezikom, premda i tu nalazimo još dosta tradicionalnih crkvenoslavenskih elemenata. To, dakako, otežava definiranje jezika ovoga teksta, to više što njegov autor, prevodilac ili prepisivač, nije bio dosljedan ni u poštivanju pisarske tradicije, ni u osjećaju svoga vlastitoga živog govora. Slika je šarolika i zamućena, ili zato jer je pisac bio opterećen tradicijom, ili pak zato što se svjesno želio što više približiti knjiškim jezičnim formama“. .38

Koji su tekstovi u Ivančićevu zborniku pisani pretežito crkvenoslavenskim jezikom pokazuje odabir za Rječnik crkvenoslavenskoga jezika hrvatske redakcije: Legenda o sv. Mariji Magdaleni, razne molitve: sv. Augustina, sv. Marije, sv. Bede Časnog, sv. Tome, sv. Marije, sv. Klimenta pape, sv. Bernarda, Poslanice sv. Jeronima.

\section{Leksik Ivančićeva zbornika}

Zanimljivo je da u trajnom nastojanju oko razumljivosti upravo u 15 . stoljeću - u razdoblju oštre dijalekatske diferenciranosti - dio glagoljaških pisaca ocjenjuje da je za što širu prihvatljivost jezika njihovih spisa posve dostatno lako obojenje: površinska impregnacija čakavske osnove nekim kajkavskim izrazima. Znatno je rjeđe suprotno. ${ }^{39}$ Činjenica da u čakavskim tekstovima ima štokavskih i kajkavskih leksema, u štokavskim čakavskih i kajkavskih, a u kajkavskim

\footnotetext{
NAZOR 1963: 85.

38 PETROVIĆ 1972: 144.

39 HERCIGONJA 1983: 332.
} 
čakavskih i štokavskih, pokazuje da je u tadašnjih hrvatskih pisaca postojala svijest da ti leksički elementi čine jedno vrelo. ${ }^{40}$ Leksik je hrvatskih tekstova 16. stoljeća podloga za proučavanje dodira hrvatskoga jezika s drugim jezicima i leksičkoga posuđivanja.

Za 16. je stoljeće karakteristično postojanje aloleksa različite područne proširenosti i otvorenosti prema leksiku svih tadašnjih hrvatskih idioma. ${ }^{41}$ Ova je tendencija poznata još od 15. stoljeća. Razvija se stvaranjem hibridnoga čakavskokajkavskoga jezika, posebice na područjima koja su pripadala knezovima Frankapanima, kako u književnim tekstovima, tako i u pravno-povijesnim listinama. ${ }^{42}$ To potvrđuju i brojni primjeri iz CIvan, npr.:

Toliko toliko slabi i toliko mled'ni (73),

$d(u)$ ša ê t(a)ko slaba i m'led'na da se pustila premocii (86 $\left.6^{\mathrm{v}}\right)$.

Svrha je hibridnoga književnojezičnoga tipa razumljivost na što većem dijelu nacionalnoga prostora ${ }^{43}$, a to se na leksičkom planu postiže uporabom tzv. kontaktnih sinonima. „S obzirom na izrazit komunikacijski senzibilitet naših srednjovjekovnih pisaca, razumljivo je da se njihovo vođenje računa o razumljivosti, o lokalnim govornim razlikama, najintenzivnije očituje upravo na području leksičkog odabira, frekventnom zastupljenošću, kontaktnih (eksplikativnih) i distaktnih sinonima (što u njih postaje manirom, štoviše stilskom značajkom)“". ${ }^{44}$ U Ivančićevu zborniku najviše ih je u Traktatu, npr.: gnêvb ali sr'da, prazdanb ali lênostb, lakomiê ali hl'postb, bljud'stvo ali ljubodêenie ( $\left.2^{\mathrm{r}}\right)$, ipokriziê ali licemêrie $\left(3^{\mathrm{v}}\right)$, nature ali $n^{\prime r a v a}\left(4^{v}\right)$, vražitelnice i bahornice ( $\left.5^{v}\right)$, špotb i rugo ( $\left.8^{\mathrm{r}}\right)$, svoimb naputomb ili sinov'cemb (31'), kaštigati i karati $\left(26^{\mathrm{v}}\right)$, zlobb ili men'du (34), svade i r'vane $\left(48^{\mathrm{r}}\right)$, krasti i v'zeti tue (48), govore vitru i aeru $\left(49^{\mathrm{v}}\right)$, zabaêv'ci ili vl'havci (51'v). Nisu neobične ni rečenice s nizom sinonima, npr.: ti si v'velici raskoši resalb $i$ esi mnogo dilikanb ili prokšens i tan 'ka n'rava ti neĉb moĉb činiti ili s'postoêti velike pokore ni žežini ni ine okorĉine $\left(18^{v}-19^{r}\right)$.

Miješanje je jezičnih starocrkvenoslavenskih i starohrvatskih elemenata jedno od najuočljivijih obilježja srednjovjekovnih hrvatskih tekstova, posebice beletrističkih. Udio je tih sastavnica različit od teksta do teksta. Pri nastanku tekstova, pisci su rezultate duge tradicije (leksik, frazeologija, terminologija) ugrađivali u nove stilizacije hrvatskoga književnoga jezika. ${ }^{45}$

\footnotetext{
40 SAMARDŽIJA 2011: 446.

$41 \quad \mathrm{Na}$ istome mjestu.

42 HERCIGONJA 1983: 329.

43 DAMJANOVIĆ 2009: 400.

44 HERCIGONJA 1983: 355; VONČINA 1988: 194.

45 DAMJANOVIĆ 2009: 400.
} 


\section{Crkvenoslavenski leksik}

Prvi slavenski književni jezik, starocrkvenoslavenski, nije bio ni prostorno ni vremenski jedinstven sustav jer je služio mnogim slavenskim narodima sa širokoga područja i iz različitog vremena. Sačuvani su spomenici proistekli iz različitih oblasti i pokazuju jezična obilježja svoga kraja ili miješani karakter. ${ }^{46}$ Nejedinstvenost se posebice očituje na leksičkoj razini jer je leksik najpromjenjiviji dio jezičnoga sustava. To se objašnjava činjenicom da je, od svih jezičnih elemenata, leksik u najtješnjoj vezi s vanjskim svijetom te u jezik treba unijeti sve promjene iz vanjskoga svijeta. ${ }^{47}$

Hrvatski crkvenoslavenski jezik, odnosno crkvenoslavenski jezik hrvatske redakcije, naslijedio je mnoge karakteristike starocrkvenoslavenskoga jezika, pa tako i temeljne leksičke slojeve: praslavenski sloj, grecizme, romanizme, moravizme, germanizme, ohridizme i preslavizme. Protokom vremena u hrvatskoglagoljske se tekstove sve više unose kroatizmi, nešto manje u liturgijske, a znatno više u neliturgijske. Govoreći o leksiku hrvatskoglagoljskih tekstova, treba imati na umu da se u njima promiješao leksik različitih slojeva. Kad je riječ o crkvenoslavenskom, čakavskom i kajkavskom prepletanju, ne smijemo zaboraviti na činjenicu da je riječ o genetski srodnim jezičnim sustavima. Stoga je katkad teško odrediti što pripada kojem sustavu, posebice na leksičkoj razini jer su neki leksemi zajedničko čakavsko-kajkavsko blago. Jezično interferiranje, kao sastavni dio problematike miješanja jezika, najbolje se očituje na planu leksičkih jedinica, tj. leksičke jedinice dominiraju nad fonološkim, morfološkim i sintaktičkim. ${ }^{48}$

Kao što je utvrdio Stjepan Damjanović ${ }^{49}$, staroslavenizmi su u cjelini hrvatskoglagoljskih neliturgijskih tekstova najčešće vezani uz biblijski kontekst, tj. najčešći su ondje gdje se citira ili prepričava Biblija. Takve primjere nalazimo i u Ivančićevu zborniku:

$A(z b)$ splju a sr(db)ce moe b'ditb (138v),

B(ož)e moi vskuju me esi ostavilb (144r),

$O\left(t_{b}\right)$ če v ruci tvoi predaju duhb moi $\left(144^{\mathrm{r}}\right)$,

s'hrani me g(ospod)i da ne postiždju se êko upvahb na te (145'),

$m(i) l(o) s(t i) v b$ i cedar'g(ospod) b $p(i) c \hat{u}$ dalb e(stb) boecim'se ego $\left(181^{\mathrm{r}}\right)$,

Se d(a)nb ï̌e stv(o)ri g(ospod)b (181v),



\footnotetext{
MARTI 1994: 23.

Isto: 24.

48 GAČIĆ 1979: 44.

49 DAMJANOVIĆ 2008: 205.
} 
Starocrkvenoslavenski arhaični sloj leksema:

Poslanice sv. Jeronima:

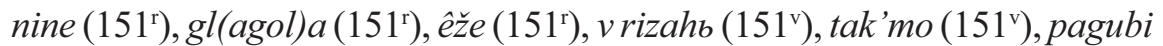
$\left(152^{\mathrm{r}}\right)$, trikratb $\left(152^{\mathrm{r}}\right)$, rabomb $\left(152^{\mathrm{v}}\right)$, blagouhaniê $\left(153^{\mathrm{v}}\right)$, tagda $\left(153^{\mathrm{v}}\right)$, ace $\left(154^{\mathrm{v}}, 163^{\mathrm{v}}\right)$, sетu $\left(156^{\mathrm{v}}\right)$, bez'čislnihb $(156 \mathrm{v})$, zastupb $\left(157^{\mathrm{r}}\right)$, eterb $(157 \mathrm{v}$, 166r, 167r), azb/az' $\left(159^{\mathrm{r}}, 166^{\mathrm{r}}\right)$, Jutru že biv'šu $\left(159^{\mathrm{r}}\right)$, ničtože $\left(159^{\mathrm{v}}\right)$, čaem ' $\left(161^{\mathrm{r}}\right)$, bes'pečalna $\left(161^{\mathrm{r}}\right)$, uprašaeši $\left(162^{\mathrm{v}}\right)$, cenen'cih' $\left(171^{\mathrm{r}}\right)$, vêrugami $\left(171^{\mathrm{v}}\right)$. Mirakuli Marije Magdalene:

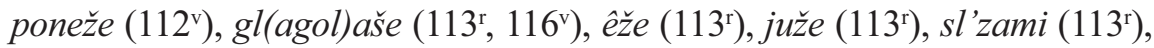
sl'nčni $\left(113^{\mathrm{r}}\right)$, parêsêi $\left(113^{\mathrm{r}}\right), k r(\hat{e})$ pko $\left(113^{\mathrm{r}}\right)$, črêvo $\left(113^{\mathrm{v}}\right)$, sas'ca $\left(113^{\mathrm{v}}\right)$, ei $\left(113^{\mathrm{v}}\right)$, slovo $\left(114^{\mathrm{r}}, 114^{\mathrm{v}}\right)$, sa $\left(114^{\mathrm{r}}\right)$, inihb $\left(114^{\mathrm{r}}\right)$, tak'mo $\left(114^{\mathrm{r}}\right)$, eterimb $\left(114^{\mathrm{r}}\right)$, vonju blagouhaniê $\left(114^{v}\right)$, tomžde $\left(115^{v}\right)$, egda $\left(115^{\mathrm{r}}\right)$, vsedannihb $\left(115^{\mathrm{v}}\right)$, otveça $\left(115^{\mathrm{v}}\right)$, piĉu $\left(116^{\mathrm{r}}, 117^{\mathrm{r}}\right)$, otroče $\left(116^{\mathrm{v}}, 117^{\mathrm{r}}\right)$, dokolê $\left(116^{\mathrm{v}}\right)$, emuže $\left(117^{\mathrm{r}}\right)$, rabi $\left(118^{\mathrm{r}}\right)$, êkože $\left(118^{\mathrm{v}}\right), t^{\prime} g d a\left(118^{\mathrm{v}}\right)$, abie $\left(120^{\mathrm{r}}, 121^{\mathrm{v}}\right)$, gl(agol)ahu $\left(121^{\mathrm{v}}\right), a z^{\prime}\left(122^{\mathrm{r}}\right)$. Različite molitve:

račilb esi $\left(135^{\mathrm{v}}, 139^{\mathrm{v}}, 144^{\mathrm{r}}\right)^{50}$, ispovêdaemb $\left(135^{\mathrm{v}}\right)$, v' inom ' $\left(135^{\mathrm{v}}\right)$, priležno $\left(135^{\mathrm{v}}, 136^{\mathrm{r}}\right)$, goruciago $\left(136^{\mathrm{r}}\right)$, ot črêva $\left(136^{\mathrm{r}}, 139^{\mathrm{v}}\right)$, dresel'stva $\left(136^{\mathrm{r}}\right)$, az' $\left(136^{\mathrm{r}}\right)$, istoč'nik's'l'zb $\left(137^{\mathrm{r}}\right)$, edinočedi $\left(139^{\mathrm{r}}\right)$, drêselihb $\left(139^{\mathrm{v}}\right)$, rizu $\left(140^{\mathrm{r}}\right)$, skozi $\left(141^{\mathrm{r}}\right)$, rači $\left(141^{\mathrm{r}}\right)$, juže $\left(141^{\mathrm{r}}, 143^{\mathrm{r}}\right)$, egda $\left(141^{\mathrm{r}}\right)$, êkože $\left(142^{\mathrm{v}}, 144^{\mathrm{r}}\right)$, edinočedago $\left(143^{\mathrm{r}}\right)$, vskuju $\left(144^{\mathrm{r}}\right)$, sego $\left(144^{\mathrm{r}}\right)$, da ne postiždju se $\left(145^{\mathrm{v}}\right)$, vsemogi $\left(146^{\mathrm{v}}\right)$, shrani $\left(146^{\mathrm{v}}\right)$, kolêsnicahb $\left(147^{\mathrm{r}}\right)$, črêvê $\left(147^{\mathrm{r}}\right)$, sega $\left(148^{\mathrm{r}}\right)$, kolikokratb (148'), bljudecihb $\left(148^{\mathrm{r}}\right)$, raba $\left(148^{\mathrm{r}}\right)$, siju $\left(148^{\mathrm{v}}\right)$, Iže koliždo $\left(150^{\mathrm{v}}\right)$. Mirakuli Blažene Djevice Marije:

eterb $\left(94^{\mathrm{r}}, 96^{\mathrm{r}}, 99^{\mathrm{v}}\right)$, abie $\left(94^{\mathrm{r}}, 94^{\mathrm{v}}\right)$, otrokb $\left(94^{\mathrm{r}}\right)$, gl (agol)juci $\left(94^{\mathrm{v}}, 97^{\mathrm{r}}, 98^{\mathrm{v}}\right)$, inimb (94v), uprašaše $\left(94^{v}\right)$, krotko $\left(94^{v}\right)$, na kiždo d(a)nb $\left(96^{r}\right)$, otveçav'ši $\left(96^{r}\right)$, azb $\left(96^{\mathrm{v}}\right)$, bolêzni $\left(96^{\mathrm{v}}\right)$, tagda $\left(96^{\mathrm{v}}\right)$, priskrbna $\left(97^{\mathrm{r}}\right), b(i)$ si $\left(97^{\mathrm{r}}, 99^{\mathrm{v}}, 101^{\mathrm{v}}, 105^{\mathrm{r}}\right)$, prašahu $\left(97^{\mathrm{r}}\right)$, žitie $\left(97^{\mathrm{r}}\right)$, sego $\left(97^{\mathrm{r}}\right)$, navlaĉb $\left(97^{\mathrm{v}}, 98^{\mathrm{r}}\right)$, inihb $\left(97^{\mathrm{v}}\right)$, iže $\left(98^{\mathrm{r}}\right)$, otročetema $\left(98^{\mathrm{r}}\right)$, pečalno $\left(98^{\mathrm{r}}\right)$, dreselb $\left(99^{\mathrm{r}}\right)$, zajutra $\left(99^{\mathrm{r}}\right)$, mimogreducihb $\left(99^{\mathrm{v}}\right.$, $\left.104^{\mathrm{v}}\right)$, obaruetb $\left(100^{\mathrm{r}}, 102^{\mathrm{v}}\right)$, rabi $\left(101^{\mathrm{v}}\right)$, siko $\left(102^{\mathrm{r}}\right)$, upvajucago $\left(102^{\mathrm{r}}\right), r^{\prime}$ vani $\left(102^{v}\right)$, žitiê $\left(102^{v}\right)$, dreselstva $\left(103^{\mathrm{r}}\right)$, dreseleĉi $\left(104^{\mathrm{v}}\right)$, ot neduga $\left(106^{\mathrm{r}}\right)$, ne priležno $\left(106^{\mathrm{v}}\right)$, neizglagolitelnimi $\left(107^{\mathrm{r}}\right)$, mazdu $\left(107^{\mathrm{v}}\right)$, ot strugi ričnie $\left(107^{\mathrm{v}}\right)$, na kiždo $\left(107^{\vee}\right)$, vinu Dêva $\left(110^{v}\right)$, otvêtnice $\left(110^{v}\right)$, dreseli $\left(111^{\mathrm{r}}\right)$, vetvie $\left(111^{\mathrm{r}}\right)$.

50 Premda je leksem račiti kategoriziran kao moravizam, u novije se vrijeme sve više ističe da je taj izraz potvrđen i u čakavskim govorima u značenju ,imati volju“, „priželjkivati“, ,„ostojati“”. Nalazi se u Vrbničkom statutu: ako tri od teh neje bližih ne bi račil priseći, da jej ništar neudi (f. 48). Nalazi se i u mlađim latiničnim rukopisima, primjerice u creskom prikazanju Muka Gospodina našega (s kraja 17. i početka 18. stoljeća): i blažena ona mati ka te rači k nam poslati (420); rači svih nas poslušati i svim tvoju milost dati (427). Najnovija istraživanja potvrđuju da se leksem račiti, uz žuk, genuti se itd. ubraja u zajednički starohrvatski leksik, tj. i štokavski i kajkavski i čakavski (v. MARESIĆ 2006). Leksem je račiti uobičajen i u današnjim bugarskim govorima (v. RIBAROVA 2005: 27). 
Traktat o sedam smrtnih grijeha:

$r^{\prime}$ vanju $\left(1^{\mathrm{r}}\right)$, bljud'stvo $\left(2^{\mathrm{r}}\right)$, ljubodêenie $\left(2^{\mathrm{r}}\right)$, rasoh' $\left(2^{\mathrm{r}}\right)$, pagubi $\left(2^{\mathrm{v}}-3^{\mathrm{r}}\right)$, vsagda $\left(4^{\mathrm{r}}\right)$, ne rači $\left(4^{\mathrm{v}}\right)$, čislo $\left(5^{\mathrm{r}}\right)$, pod'lastavcevb $\left(7^{\mathrm{v}}-8^{\mathrm{r}}\right)$, basiliskb $\left(14^{\mathrm{r}}\right)$, pagubanb $\left(14^{\mathrm{r}}\right)$, dotolê $\left(15^{\mathrm{v}}\right)$, dokolê $\left(15^{\mathrm{v}}\right)$, nedugb $\left(21^{\mathrm{r}}\right)$, tat $\left(25^{\mathrm{r}}\right)$, tat'ba $\left(25^{\mathrm{r}}\right)$, goraz'dastvo $\left(28^{v}\right)$, rotiti se $\left(33^{v}\right)$, opona $\left(34^{\mathrm{r}}\right)$, bližika $\left(38^{v}\right)$, daždb $\left(40^{v}\right)$, moš'na $\left(45^{\mathrm{r}}\right)$, tlsto $\left(45^{\mathrm{r}}\right)$, tlste riči $\left(57^{\mathrm{v}}\right)$, vaĉina $\left(48^{\mathrm{v}}\right)$, piĉah $\left(46^{\mathrm{v}}\right)$, piĉ́nik $\left(47^{\mathrm{r}}\right)$, pecera $\left(48^{\mathrm{r}}\right)$, istlkovaniju $\left(48^{\mathrm{v}}\right)$, oĉasb $\left(52^{\mathrm{v}}\right)$, okrutb $\left(49^{\mathrm{r}}\right)$.

Tumačenje misnog obreda, Pitanja i odgovori, Blagoslov stola račiše $\left(172^{v}\right)$, trikratb $\left(175^{v}\right)$, pl'kb $\left(176^{\mathrm{r}}\right)$, vidimo $\left(176^{\mathrm{v}}\right)$, pagubu $\left(176^{\mathrm{v}}\right)$, pl'ka $\left(176^{\mathrm{v}}\right)$, blagodêêniê $\left(177^{\mathrm{r}}\right)$, taĉad' $\left(177^{\mathrm{r}}\right)$, pečal'nimb $\left(177^{\mathrm{r}}\right)$, skan'dêlb $\left(177^{\mathrm{r}}\right)$, mazdê $\left(177^{\mathrm{r}}\right)$, otvêtb $\left(177^{\mathrm{r}}\right)$, Siko $\left(177^{\mathrm{v}}\right)$, podobanb $\left(177^{\mathrm{v}}\right)$, Adê $\left(178^{\mathrm{r}}\right)$, kedra $\left(178^{\mathrm{r}}\right)$, Čipris $\left(178^{\mathrm{r}}\right)$, v adê $\left(178^{\mathrm{v}}\right)$, sl'nca $\left(179^{\mathrm{r}}\right)$, vasb mirb $\left(179^{\mathrm{r}}\right), v$ črivi $\left(179^{v}\right)$, č'rez' $\left(179^{v}\right)$, čr'm'noe $\left(179^{v}\right)$, stlpi $\left(179^{v}\right)$, rači $\left(180^{v}\right)$.

\section{2. Čakavizmi}

Hrvatskoglagoljski su neliturgijski tekstovi uglavnom pisani mješavinom crkvenoslavenskoga i starohrvatskoga jezika, a „miješanje staroslavenskih i starohrvatskih elemenata (je) prevladavajuća tendencija i to će miješanje poslužiti kao uzor miješanju čakavskih, kajkavskih i štokavskih elemenata na različitim mjestima i u različitim oblicima, uvijek s namjerom da se stvori književni jezik prihvatljiv na što širem terenu“ “. ${ }^{51} \mathrm{U}$ hrvatskoglagoljske su se rukopise postupno unosile osobine govornoga jezika (čakavski idiom), i to ne samo u neliturgijskim rukopisima, nego i u liturgijskim, posebice u onim mlađima (Hrvojev misal) ${ }^{52}$, ali i u starijima (Brevijar Vida Omišljanina ${ }^{53}$, Akademijin brevijar ${ }^{54}$ ). Josip Tandarić, zamijetivši da je utjecaj govora izraženiji u rubrikama, piše sljedeće: „S obzirom na prodor narodnoga govora, u liturgijskim je tekstovima lako odvojiti sakralni tekst od rubrikâ. Kao po pravilu u rubrikama više dolazi do izražaja govorni jezik, dapače i u terminologiji (...) imamo npr. u sakralnom tekstu prazdnikb, a u rubrikama redovito blagdan ${ }^{\text {" } .55}$ Nadalje, smatra da je prodor narodnoga govora u rubrike nastao zbog različitoga shvaćanja uloge jezika, a ne zbog neznanja pisara: „Pogrešno bi bilo i u ovom slučaju prodora narodnoga govora u rubrike vidjeti nesposobnost i nemoć prevodioca. Ako je prevodilac umio i znatno kompliciranije sadržaje s latinskoga prevesti više ili manje korektno na crkvenoslavenski, onda je tako mogao napraviti i u rubrikama" ${ }^{56} \mathrm{U}$ tekstovima pisanima crkvenoslavenskim

\footnotetext{
DAMJANOVIĆ 2014: 34.

NAZOR 1973: 509.

53 MIHALJEVIĆ 1997.

34 ŠIMIĆ 2014.

55 TANDARIĆ 1993: 73.

$56 \mathrm{Na}$ istome mjestu.
} 
jezikom, tj. liturgijskim, prevladavaju crkvenoslavenske osobitosti, a kroatiziranje je snažnije na fonetsko-fonološkoj i leksičkoj razini.

Kad u Ivančićevu zborniku govorimo o čakavskom utjecaju na leksičkoj razini, važno je napomenuti da je u gotovo svim tekstovima potvrđena zamjenica $\check{c} a-$ kriterij najvišega ranga pri određivanju čakavskoga narječja ${ }^{57}$, osim u Poslanicama sv. Jeronima. Međutim, i u tom se tekstu, kao i u svim ostalima, često upotrebljava izvanredan indikator za određivanje izvornosti čakavskoga narječja: prijedlog + $\check{c} a \rightarrow z a c ̌ c '\left(152^{\mathrm{r}}\right)$.

O jezičnom previranju u doba pisanja rukopisa i o različitim rješenjima o kojima je razmišljao pisac svjedoče primjeri u kojima se u jednoj sintagmi ili riječi prepleću dva jezična sustava, npr. čakavski i crkvenoslavenski: teš 'kov' mazdov' (174v), pri čemu je leksem iz starijega, a gramatički morfem iz mlađega jezika. Slično je i u primjerima: svoev'velikomb silov' $\left(27^{\mathrm{r}}\right)$, svoimb bližikovb ili svoevb bližikovb $\left(39^{\mathrm{v}}\right)$. U našim su tekstovima takve interferencije prilično rijetke, za razliku od sinonima. ${ }^{58}$

Primjeri:

Poslanice sv. Jeronima:

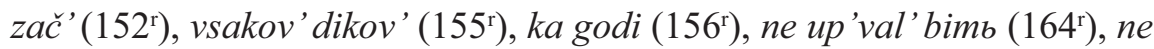
mogal'bim' (164'), kada (164'), jure (164').

Mirakuli Marije Magdalene:

ča $\left(115^{\mathrm{r}}, 116^{\mathrm{v}}\right)$, zač $\left(114^{\mathrm{v}}, 116^{\mathrm{r}}, 116^{\mathrm{v}}\right)$, volevb $(112 \mathrm{v}), k a\left(113^{\mathrm{v}}\right)$, važgal $\left(115^{\mathrm{r}}\right)$, žaju $\left(115^{\mathrm{r}}\right)$.

Različite molitve:

ča $\left(135^{\mathrm{v}}, 137^{\mathrm{r}}, 138^{\mathrm{v}}, 143^{\mathrm{v}}\right), k i\left(143^{\mathrm{r}}, 145^{\mathrm{r}}, 146^{\mathrm{v}}\right)$, poklaknuvb $\left(143^{\mathrm{r}}\right)$, začb $\left(148^{\mathrm{r}}, 149^{\mathrm{r}}\right)$, likarb $\left(136^{\mathrm{v}}\right)$, na didinu $\left(136^{\mathrm{v}}\right)$, gdi $\left(137^{\mathrm{r}}\right)$, v riči $\left(139^{\mathrm{r}}\right)$, utišenie $\left(139^{v}\right)$, Divo $\left(140^{v}\right)$.

Zanimljiv je postupak prevoditelja, u kojemu su svakodnevne riječi čakavske, a neke biblijske sintagme iz crkvenoslavenskoga, npr. gdi e istočnik' s'l'zb $\left(137^{\mathrm{r}}\right)$.

Mirakuli Blažene Djevice Marije:

začb $\left(94^{\mathrm{r}}, 95^{\mathrm{r}}, 96^{\mathrm{v}}, 97^{\mathrm{v}}\right)$, poča $\left(94^{\mathrm{v}}, 98^{\mathrm{v}}, 101^{\mathrm{r}}, 103^{\mathrm{r}}\right), \operatorname{ditic} a\left(94^{\mathrm{v}}, 95^{\mathrm{r}}, 98^{\mathrm{r}}, 103^{\mathrm{v}}\right)$, gospoê $\left(95^{\mathrm{r}}\right)$, poklaknuti $\left(95^{\mathrm{r}}\right)$, často $\left(96^{\mathrm{v}}, 105^{\mathrm{r}}, 105^{\mathrm{v}}\right)$, ciĉb $\left(97^{\mathrm{r}}\right)$, gremb $\left(97^{\mathrm{r}}\right.$, vazamb $\left.98^{\mathrm{r}}, 105^{\mathrm{v}}\right)$, počasta $\left(98^{\mathrm{r}}\right)$, poklaknusta $\left(98^{\mathrm{r}}\right), k i\left(100^{\mathrm{r}}, 100^{\mathrm{v}}\right), \mathrm{ka}\left(101^{\mathrm{r}}\right)$, $\check{c} a\left(101^{\mathrm{r}}, 103^{\mathrm{v}}, 109^{\mathrm{r}}\right)$, mani $\left(101^{\mathrm{r}}, 104^{\mathrm{r}}, 104^{\mathrm{v}}\right)$, ednovb $\left(103^{\mathrm{v}}\right)$, zlatovb $\left(103^{\mathrm{v}}\right)$, jure $\left(104^{\mathrm{r}}\right)$, prokla $\left(105^{\mathrm{v}}\right)$, proklatstvo $\left(105^{\vee}\right)$, Vazamb $\left(105^{\mathrm{v}}\right)$, sobovb $\left(108^{\mathrm{v}}\right)$, poklaknuvb $\left(108^{\mathrm{v}}\right)$, klaknu $\left(111^{\mathrm{r}}\right)$, resti $\left(111^{\mathrm{r}}\right)$.

Traktat o sedam smrtnih grijeha:

ča $\left(1^{\mathrm{v}}, 5^{\mathrm{v}}, 7^{\mathrm{r}}, 8^{\mathrm{r}}, 17^{\mathrm{v}}\right)$, sa sobovb $\left(3^{\mathrm{r}}\right)$, často $\left(4^{\mathrm{r}}, 6^{\mathrm{r}}\right)$, vaz'me tuega $\left(7^{\mathrm{v}}\right)$, malina $\left(10^{\mathrm{r}}\right)$, začb $\left(11^{\mathrm{r}}, 13^{\mathrm{v}}, 15^{\mathrm{v}}, 16^{\mathrm{v}}, 24^{\mathrm{v}}\right)$, počato $\left(14^{\mathrm{r}}\right)$, svoevb volevb $\left(14^{\mathrm{r}}\right)$, are $\left(14^{\mathrm{r}}\right)$,

\footnotetext{
57 MOGUŠ 1977: 20.

58 DAMJANOVIĆ 2014: 30.
} 
svoevb moĉevb $\left(14^{v}\right)$, sa sobovb $\left(16^{\mathrm{r}}\right)$, jure $\left(16^{\mathrm{r}}\right)$, žatva $\left(24^{\mathrm{v}}\right)$, klatve $\left(34^{\mathrm{v}}\right)$, často $\left(35^{\mathrm{r}}\right)$, zrestaju $\left(30^{\mathrm{r}}\right)$, restenie $\left(23^{\mathrm{r}}\right)$, ematvi $\left(24^{\mathrm{v}}\right)$.

Tumačenje misnog obreda, Pitanja i odgovori, Blagoslov stola: ere $\left(172^{\mathrm{r}}\right)$, ča dimo $\left(172^{\mathrm{r}}\right)$, govori $\left(172^{\mathrm{v}}\right)$, začb $\left(172^{\mathrm{v}}, 172^{\mathrm{v}}, 173^{\mathrm{v}}, 174^{\mathrm{r}}, 178^{\mathrm{r}}\right)$, nere $\left(173^{\mathrm{r}}\right)$, počali $\left.173^{\mathrm{r}}\right)$, vazmet' $\left(173^{\mathrm{v}}\right)$, počati $\left(173^{\mathrm{v}}\right), \check{c} a\left(174^{\mathrm{r}}, 175^{\mathrm{v}}\right)$, vazda $\left(174^{v}\right)$, poča $\left(174^{v}\right)$, govoriti $\left(174^{v}\right)$, teš 'kov'mazdov' $\left(174^{v}\right)$, počala $\left(175^{\mathrm{r}}\right)$, ciĉb $\left(175^{\mathrm{v}}, 177^{\mathrm{v}}\right)$, rukov' $\left(175^{\mathrm{v}}\right)$, kadi $\left(175^{\mathrm{v}}\right)$, česo $\left(178^{\mathrm{r}}\right)$.

\section{Kajkavizmi}

Kao što je poznato ${ }^{59}$, kajkavska jezična sastavnica ulazi u hrvatsku književnost najmanje stoljeće prije protestantizma, a čak dva prije Ozaljskoga književnoga kruga, dakle već početkom 15 . stoljeća i to u hrvatskoglagoljskim zbornicima. Već je kajkavizme u Kolunićevu zborniku zamijetio Matija Valjavac ${ }^{60}$, a Franjo Fancev upozorio je na činjenicu da se kajkavska književna riječ davno prije reformacije dodirivala s čakavskom. ${ }^{61}$ Najveći broj važnih spoznaja o prodoru kajkavizama u hrvatskoglagoljsku književnost dugujemo Eduardu Hercigonji, koji je utvrdio da je u našim zbornicima već od početka 15 . stoljeća čakavska osnova impregnirana kajkavskim crtama, što traje na dijelu glagoljaškoga područja duboko u 16. stoljeće. Taj je prodor kajkavizama početak nastojanja da se premoste dijalektne granice. ${ }^{62}$

Prvo ozbiljnije uvođenje kajkavštine iz govorne u sferu pisane riječi čine kajkavizmi, koncentrirani u pojedinim kapitulima glagoljskih zbornika kasnoga srednjega vijeka, a među njima posebno mjesto zauzima Petrisov zbornik. Eduard Hercigonja ustanovio je da je čak jedna trećina od oko 160 članaka toga kodeksa „s promjenljivom čestoćom impregnirana kajkavizmima sviju razina“ i da takva „intenzivna interpolacija kajkavizama u hibridnu čakavsko-crkvenoslavensku strukturu zborničkih tekstova nije zastupljena ni u jednom drugom glagoljaškom spisu“. ${ }^{63}$ Vjekoslav Štefanić upozoravao je na obilježja kajkavskoga sustava u hrvatskoglagoljskim tekstovima, posebice u raznim registrima s istarskoga područja iz 16. stoljeća. Tako za Kvadrigu duhovnim zakonom navodi da je ,jezik teksta narodni, čakavski, koji ponešto ćuti blizinu kajkavskoga, na pr.: da ne bu gospodoval' $30^{\text {“ }} .{ }^{64}$ Pri tome Štefanić objašnjava kajkavizme podrijetlom te ih veže uz područje na kojemu se dodiruju čakavština i kajkavština. Damjanović pak smatra da to nije morao biti jedini razlog za uvođenje kajkavizama, nego

\footnotetext{
HERCIGONJA 1983.

VALJAVAC 1892.

FANCEV 1925: 550.

HERCIGONJA 1983: 303-385.

Isto: 309.

ŠTEFANIĆ 1960: 234.
} 
je to moglo biti povezano i s koncepcijom građenja jezika neliturgijskih knjiga, odnosno piščevim stavom. ${ }^{65} \mathrm{Kad}$ je riječ o kajkavizmima u tekstovima 15. i 16. stoljeća, otvara se niz nerazjašnjenih pitanja, od kojih su, prema Damjanovićevu mišljenju, dva najvažnija:

1. Š to se u određenom povijesnom razdoblju može smatrati kajkavizmom i kako izbjeći nesumnjivu opasnost da nas zavede naš današnji osjećaj?

2. Što je u 15. i 16. stoljeću kajkavizam, a što zajedničko blago kajkavskoga i čakavskoga narječja?

Kategorija kajkavizama u tekstovima 15. stoljeća još nije dokraja definirana ni usustavljena: „Neke riječi, kao npr. beteg, kaštigati, ili čak hiža, koje danas zbog vrlo česte upotrebe u čakavskim tekstovima i govorima ne ubrajamo u kajkavizme (beteg dolazi u Marulića, u hvarskim govorima, u Hrv. primorju, itd.) možda će ipak biti tako tretirane. Sve će to ovisiti o definiciji koja će nam reći što je kajkavizam u 15. stoljeću, definiciji, koju u ovom trenutku nemamo“ ${ }^{66}$ Pri utvrđivanju vjerojatnih kajkavskih razlikovnih obilježja, prema Eduardu Hercigonji ${ }^{67}$, moramo imati u vidu neke povijesno-dijalektne činjenice:

1. iako se dijalektni sustavi hrvatskoga jezika definitivno oblikuju, tj. diferenciraju između 12. i 15. stoljeća, sve do 14. stoljeća nisu postojale velike razlike između tih dijalekata, osobito na kopnu gdje su se prepletali

2. zapadnojužnoslavenski je prajezik imao dugo zajedništvo, najkasnije se razdvajaju primorska i panonska dijalektna grupa

3. u sklopu čakavštine uočljiva je neprijeporna naročita bliskost sjeverozapadnog čakavskoga s kajkavskim, posebice u leksiku.

U hrvatskoglagoljskim zbornicima nalazimo kajkavizme na svim jezičnim razinama: fonološkoj, morfološkoj, leksičkoj i sintaktičkoj, ali različito od kodeksa do kodeksa ${ }^{68}$ Intenzitet kajkavskih obilježja ovisi o mjestu pisanja rukopisa. U zapadnoj je skupini smanjen intenzitet kajkavskih elemenata, a postoje i određene razlike prema tipu kajkavizama. „Opći je dojam nakon pregleda stanja u kodeksima da čestoća kajkavizama u hibridnom jeziku ovih spisa (...) slabi silazeći po pravcu sjeveroistok-jugozapad (Vinodol) - zapad (Istra). Usporedo s čestoćom mijenja se i karakter kajkavskih intervencija: na sjeveru su one leksičke, fonetske i morfološke da u daljnjem kretanju prema jugu (zapadu) postepeno budu svedene pretežito na leksik “ ${ }^{69}$

Premda se Ivančićev zbornik ne ubraja u rukopise u kojima je prisutna kajkavska sastavnica jer su kajkavizmi iznimno rijetki, posebice na fonološkoj i

\footnotetext{
${ }_{65}$ DAMJANOVIĆ 1984: 154; Isti 2014: 35. 
morfološkoj razini ${ }^{70}$, ipak je na leksičkoj razini prisutno ,lako obojenje, površinska impregnacija čakavske osnove nekim od kajkavskih izraza“". ${ }^{11}$ Najviše je kajkavizama u Traktatu o sedam smrtnih grijeha. Oni su vjerojatno uneseni $\mathrm{u}$ tekst pod utjecajem predloška s kojega se prepisivalo. Većinom su poznati na čakavsko-kajkavskom području. Pripadaju zajedničkomu čakavsko-kajkavskom blagu, a katkad i štokavskomu jer su neki zabilježeni i u Dubrovniku: npr. habati, hiniti, lotar, moistar, takaiše itd..$^{72}$

Usporedimo li Traktat o sedam smrtnih grijeha iz Ivančićeva i Kolunićeva zbornika (1486. $)^{73}$, zapazit ćemo da koncentracija kajkavizama nije velika te da u Korizmenjaku Kolunićeva zbornika nalazimo znatno više kajkavizama, kao što se vidi iz primjera: nedopirb TKZ 223/prprčac TIZ 13a, mlêdnostb TKZ 230/ lênostb TIZ 21a, (ali i TIZ ima mled'nostiju 60b), strela boleštra TKZ 243/strela balistrena TIZ 37a, suprotan je primjer: moistri TIZ 28b/meštri TKZ $237 .{ }^{74}$

Primjeri:

Poslanice sv. Jeronima:

gorup'no $\left(164^{\mathrm{v}}\right) .^{75}$

Različite molitve:

pelati $\left(144^{\mathrm{v}}\right) .^{76}$

70 KOSIĆ 2010: 72; ŠIMIĆ 2005: 403-404.

71 HERCIGONJA 1983: 332.

72 Na morfološkoj je razini od izrazitih kajkavskih obilježja u CIvan zabilježen samo jedan primjer prezenta glagola biti za futur bu: da bu mu êvlena (130 , Poslanica sv. Pavla).

73 Kolunićev zbornik 1486. prepisao je po narudžbi gatanskoga vikara Levnarda pisar Broz Kolunić u Knežej Vasi kraj Otočca.

74 ŠIMIĆ 2005.

75 Prema ARj (III: 296), pridjev gorup potvrđen je kod Belostenca, Gorupac je muško ime poznato od 16. stoljeća, pridjev gorupan, gorupna poznat je u Dubašnici na Krku: Bolesniku vele da su mu usta gorupna, a glagol gorupiti potvrđen je još kod Barakovića: Jad nam stan gorupi, guja srce kine. Prema Petru Skoku (1971: 592), u kajkavskome se narječju umjesto gorak upotrebljava gorup sa sufiksom -bn, gorupan ,žuk, slan“, denominal gorupiti. U hrvatskoglagoljskim je liturgijskim rukopisima leksem ogorupiti očuvan u BrAc: otkudu ogorupit'se $43 \mathrm{~d}_{\text {i BrVat }} 40 \mathrm{~b}$. $\mathrm{Na}$ paralelnome mjestu drugi brevijari imaju ogorčit'se, npr. $\mathrm{BrN}_{2} 329 \mathrm{~b}, \mathrm{BrVb}_{4} 109 \mathrm{c}$. Leksem izveden iz iste osnove, gorupostb, nalazi se još u nekim brevijarima: gorupostb $d(u)$ ha svoego BrVO 404d, BrVat 5 217d, BrN 2 237a, gorupostiû BrBar 307d. U zbornicima je pronađen u CTk 80r: Pod sladkim medom zakriti se more gorup čemer Pod sadskimi riči sie, gorup svršue, te CAc 71: tada se isplni rêč b(la)ž(e)noga eronima ki reče o semrti slatka bi bila v paklê ka si bila gorupa na svêtê.

76 Od iste je osnove u hrvatskoglagoljskim tekstovima tvoreno više leksema: pelati, vpelati, propelivati itd. Leksem peljati, prema ARj, najviše se upotrebljava kod čakavaca i kajkavaca, a rijetko kod štokavaca. Potvrđen je kod Marulića, među ostalim arhaizmima, npr. peteh, hiža, hudo, peljati, tat, pes, meč, koji su zajedničko blago čakavskoga i kajkavskoga narječja. Često se upotrebljava u zbornicima: otvarati i propelivai v nebesa $\left(\mathrm{CTk} 57^{\mathrm{r}}\right)$, tako e umilen $\check{c}($ lovê)k v rai vpelan $\left(\mathrm{CTk} 62^{v}\right)$, Tako gredu osla pripelaju $\left(\mathrm{CTk} 113^{v}\right)$. 


\section{Mirakuli Blažene Djevice Marije: pravišb $\left(96^{r}\right)^{77}$, praveĉe $\left(100^{r}\right)$, nigdarb $\left(96^{v}\right)$. \\ Različite molitve: \\ moistar $\left(136^{\mathrm{v}}\right) .^{78}$ \\ Traktat o sedam smrtnih grijeha:}

1. čakavsko-kajkavski sloj: pravi $\left(1^{\mathrm{r}}\right)$, lotar 'stva $\left(1^{\mathrm{r}}, 19^{\mathrm{r}}, 28^{\mathrm{r}}\right)^{79}, \operatorname{hudim}\left(4^{\mathrm{r}}, 5^{\mathrm{r}}\right.$, $\left.13^{\mathrm{r}}\right)$, hudo $\left(6^{\mathrm{v}}\right)^{80}$, kaš tiga $\left(8^{\mathrm{v}}\right)$, mlednostb $\left(20^{\mathrm{r}}\right)$, takaišev' $\left(25^{\mathrm{r}}\right)^{81}$, hudimb $\left(25^{\mathrm{v}}\right)$, kaštigati $\left(26^{\mathrm{v}}\right)^{82}$, moistri $\left(24^{\mathrm{r}}, 28^{\mathrm{v}}\right)$, moistra $\left(22^{\mathrm{v}}\right)$, takoiše $\left(41^{\mathrm{v}}\right)$, lotarb

77 Na leksem praviti kao kajkavizam „in der Bedeutung reden“ upozorio je Vatroslav Jagić u Tundalovu viđenju iz CPet: od mala do velika praviti (JAGIĆ 1914: 507). Isti se leksem nalazi kod Marulića i u Lekcionaru Bernardina Splićanina. Leksem praviti često se pojavljuje u hrvatskoglagoljskim rukopisima, počevši od fragmenata iz 13. stoljeća, npr. u FgLab 2 d, u brevijarima, npr. BrVO 46c, 128d, BrVat ${ }_{6} 116 \mathrm{~d}, \mathrm{BrN}_{2} 473 \mathrm{~b}, \mathrm{BrVat}_{5} 40 \mathrm{a}$, od zbornika najčešće u CPet i COxf i u RegBen 11b: Iže pravit'g(ospod)b uzakb e(stb) put'k'životo! vêčnomu. Prema Skoku, glagol praviti u značenju „besjediti, govoriti“ potvrđen je u Dubrovniku i na Korčuli (Lumbarda). I na ćiriličnim se bosansko-humskim natpisima pojavljuje taj iznimno arhaičan leksem na Natpisu vojvode Miotoša (1399. - 1415.), što potvrđuje da je bio rasprostranjen na širokom području: ... I pravi vojvoda Miotošb: I mnogo na zemlji bi (ubijeno) a ja ni ot jene $i$ nikorb ot moje ruke ne bi mrbt(a)vb. Ne (htje)h ga ubiti (VEGO 1970: 30-31).

78 Leksem mojstar ubraja se u zajedničko čakavsko-kajkavsko blago, a najstarija je potvrda za značenje „majstor“ u hrvatskome jeziku na ćiriličnom Natpisu župana Grda iz 12. stoljeća. Ona je najvjerojatnije posuđenica iz romansko-dalmatskoga jezika (v. REINHART 1996: 172).

79 Germanizam lotar u značenju „lupež, pijanica, ljenčina“ ubraja se među lekseme koji su se iz sjevernih kajkavskih krajeva proširili i na jug. Potvrđen je na širokom području: kajkavskom, čakavskom, pa i u Dubrovniku i na Korčuli. U Istri, u Bermu, uparan je na glagoljskim grafitima: osal, lotar-pijani osal (v. FUČIĆ 1982: 22). Također se često upotrebljavao u rukopisu creske Muke Franića Vodarića, latiničnom rukopisu s konca 17. ili početka 18. stoljeća.

80 Praslavenski je i staroslavenski izraz hudъ (parvus, tenuis, pauper) imao prvotno značenje „mršav, siromašan“, (potvrđeno u Poljičkom statutu), pa je kasnije od ovih značenja nastalo „bijedan, jadan, žalostan, nevoljan“, zatim „kukavan, nevaljao, nevrijedan“, pa još gore - „zao“. Za pridjev huđi najstarije su potvrde kod N. Ranjine, Š. Menčetića, Dž. Držića, D. Ranjine,

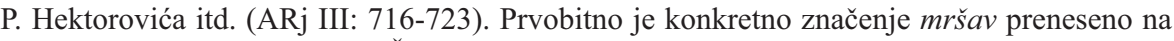
apstraktno, tj. psihičko stanje. Široko je rasprostranjeno u hrvatskim govorima, npr. imenica hudoba, koja je eufemizam za vraga na Korčuli, dok glagol hudati na Cresu ima značenje „koriti“ (SKOK 1971: 692).

81 Leksemi su takai, takaiše potvrđeni u hrvatskoglagoljskim liturgijskim rukopisima, npr. u II. novljanskom brevijaru: I potomb vrêmeni mimogreduci ot tainosti o(tb) ca b(og)a takai s(ve)tb očito pride (367a), I to takaiše govori se ot bl(a)gd(a)na s(ve)tihb (263a). Isti se leksemi često nalaze u hrvatskoglagoljskim zbornicima, npr.: takaiševb $\left(\mathrm{CKol} 233^{\mathrm{r}}\right)$. Leksemi slične tvorbe, npr. takajše, tolikajše, tolikojše poznati su i čakavskim govorima, posebice onim sjevernim. Tolikajše, na produženu osnovu tolik(aj) dodan je navezak -še, potvrđeno je u Veprinačkom statutu iz 1507. (v. KUZMIĆ 2001: 17), u Komunalu grada Senja iz 1697. (ARj XVIII: 444), u Darovnici slavnoga Dragoslava crkvi sv. Vida kod Dobrinja (v. MIHALJEVIĆ 2000: 3, 7).

82 Kaštigati pripada leksemima koji se danas zbog česte uporabe i u čakavskim govorima ne ubrajaju u kajkavizme, nego u zajedničko čakavsko-kajkavsko blago. Često se pojavljuje u našim zbornicima, npr. u CTk: ričju se na pokoru ne spravlam ni kaštigam $\left(26^{v}\right)$, ta e proklet $i$ kaštigan mnoju $\left(46^{v}\right)$, i da bi ju ne kaštigalb (77 $)$, u CKz: dokli estb gospodinb bogb ot'lučils ne oće 
$\left(42^{\mathrm{r}}\right)$, prehineni $\left(46^{\mathrm{r}}\right)^{83}$, lotar'stvo $\left(52^{\mathrm{v}}\right)$, om'led'nišb $\left(44^{\mathrm{v}}\right)^{84}$, tan'caniê $\left(62^{\mathrm{v}}\right) .{ }^{85}$

2. kajkavizmi: špot $\left(8^{\mathrm{r}}\right)^{86}$, drobnoga $\left(18^{\mathrm{r}}\right)$, riči vlh'ke $\left(33^{\mathrm{v}}\right)$, cêhu $\left(42^{\mathrm{r}}\right)$, faita $\left(34^{\mathrm{r}}\right)$, hlaps $\left(5^{\mathrm{r}}, 15^{\mathrm{v}}, 45^{\mathrm{r}}\right)$, prokšens $\left(18^{\mathrm{v}}, 21^{\mathrm{r}}\right)$, se s'hab'la $\left(45^{\mathrm{r}}\right)$, š poti $\left(47^{\mathrm{v}}\right)$.

ustati ta kaš 'tigb od'vasb (40), da govore naši duktori da ni grihb, ki veće kaš 'tiga gospodinb bogb (177). Prilično se učestalo u našim zbornicima nalaze sinonimi u trajnom nastojanju oko razumljivosti (E. Hercigonja), u ovom slučaju: kaš'tigati i karati CIvan 26b, CKz 235, a također u CTk: nere kada nego hoće pokarati i pokaštigati (84v'). Među hrvatskoglagoljskim je brevijarima kaštigati potvrđeno u $\mathrm{BrN}_{2}$ - i potom'ga krêpko kaš'tiga (373a).

83 U tekstovima nalazimo više leksema tvorenih od ove osnove: hiniti, prehiniti, himba, hinac u značenju ,prevariti, prijevara, varka“, a mogu se ubrojiti u zajedničko blago dvaju narječja. Potvrde su u rječnicima od 15. stoljeća: Vrančić, Mikalja, Belostenec, Jambrešić, Stulić. Leksem je potvrđen u Lekcionaru Bernardina Splićanina, kod M. Marulića, N. Ranjine, Dž. Držića, M. Vetranovića itd. (ARJ III: 599, 603). U Tkonskom se zborniku taj leksem nalazi gotovo u svim dijelovima, a najčešći je u Muci: ki po dêvli prehineni biste na smrt osueni $\left(8^{v}\right)$.

84 Leksem mleden, između ostaloga, žuk, račiti, genuti se, ubraja se u zajednički starohrvatski leksik, odnosno i u štokavski i u kajkavski i u čakavski (v. MARESIĆ 2006). Prema Skoku (1972: 442), taj je pridjev potvrđen i u Dubrovniku, a u ikavskom obliku mlidan i u Slavoniji, te može imati dva značenja: 1. „mršav, suh“, i 2. „bljutav, neslan“ (Krk). Leksem se mledbnb nalazi i u II. novljanskom brevijaru (1495.): t(ê)lo m'led'no (364d), kao i u Petrisovu zborniku: imei v pameti tvoju mlednost $\left(106^{v}\right)$.

85 Leksem tanac stara je hrvatska posuđenica iz srednjevisokonjemačkoga - Tanz, a od hrvatskoglagoljskih rukopisa potvrđena je u Novakovu misalu iz 1368., ali i u nekim drugim misalima kojima MNov nije mogao biti predložak: $\mathrm{MLab}_{2}, \mathrm{MVat}_{8}, \mathrm{MVb}_{1}, \mathrm{MOxf}_{1}, \mathrm{MOxf}_{2}, \mathrm{MHrv}, \mathrm{MBer}$ i MNew. Stoga se može pretpostaviti da je postojao jedan arhetip misalskoga rukopisa koji je imao leksem tanacb (za lat. chorum), najkasnije iz prve polovine 14. stoljeća, koji se nije očuvao (REINHART 1990: 202). Budući da je u njemačkome taj leksem poznat još od 1200., u hrvatski je jezik mogao ući između 1200. i prve polovine 14. stoljeća (REINHART 1990: 203). Tanac je jedan od germanizama, koji se iz sjevernih proširio i na južne krajeve. Poznat je od Istre i Krka, pa sve do Dubrovnika, a zanimljivo je da se na jugu češće rabi germanizam, negoli romanizam (SKOK 1973: 442). Često se nalazi u zbornicima, npr. u CTk: Esi li se opiêl v s(ve)te d(b)ni ili tance vodil, kako pravi s(ve)ti Avguštinb: Ke v s(ve)tke tance vodi ili se opija, veći grih mu e nere orati ili kopati! A to est zato ere e tanac vražja voiska na Boga i koliko e koli v tanci žen urešenih $\left(96^{\mathrm{r}}\right)$, Esi li hodil gledati tancev (97r). U CKz nalazimo tanacb (200) i tancanie (CKz 264). Ovaj je leksem još jedna potvrda o kontinuitetu hrvatske književnosti, od hrvatskoglagoljskih misala preko zbornika do kasnije književnosti, npr. Džore Držića.

Germanizam špotati (od njem. spotten), u značenju ,rugati se“, prema P. Skoku poznat od 16. stoljeća kod čakavskih i kajkavskih pisaca, a od rječnika nalazi se kod Belostenca, Della Belle i Habdelića. Međutim, u hrvatskoglagoljskim je rukopisima zasvjedočen još od 15. stoljeća. I dok se leksemi špotb, špotati se često pojavljuju u hrvatskoglagoljskim zbornicima, npr. Kadê su ki se vêrnomu špotahu i s'mêêhu (CPet 345'), od smijucih se i špotajucih'se (CAc 70'), O gore špotajucimi se s(ve) timi knigami (CPet 346v) itd., među liturgijskim je rukopisima potvrđen jedino u Pašmanskom brevijaru (druga polovina 14. i 15. stoljeće): i prêdast'se narodom' na poruganie i tepenie i n'raspetie i š potanie muke ( $\mathrm{BrPm} 212 \mathrm{~d})$. Leksemi špotb i pošpotati učestalo se pojavljuju u CKz i CIvan, npr. špotb CKz 29, 36, 125, 219 itd., pošpotati CKz 36, 51, 64, 92, 95, 122 (VALJAVAC 1892: XXVII.). U CTk: kako se mi špotahomo mej sobu nevolnimi $\left(33^{v}\right)$, krotkimi špotajući se (34), Tu Pilat popela Isusa vnutr i čini ga kruniti i biti i pošpotati $\left(145^{\vee}\right)$, Tu židove špotaju se i reku $\left(154^{v}\right)$, Tu razboinik levi špotae se i reče $\left(154^{v}\right)$. 
Tumačenje misnog obreda, Pitanja i odgovori, Blagoslov stola: hudobah $\left(175^{v}\right)$, tretič $\left(175^{v}\right) .87$

Zajedničko čakavsko kajkavsko blago: gdo $\left(179^{\mathrm{r} 88}, 179^{\vee}\right)$, lah'ko $\left(176^{\mathrm{r}}\right)$, daždb $\left(180^{\mathrm{r}}\right)$.

\section{Romanizmi}

Kad je riječ o latinskom utjecaju u hrvatskoglagoljskim tekstovima, razlikujemo najmanje tri sloja:

1. latinizmi posuđeni u hrvatski jezik iz balkanskoga latiniteta s prvim prijevodima liturgijskih knjiga, npr. kaležb, križb, mbša, olbtarb, ocbtb, poganъ, kombkanie

2. latinizmi koji su ušli u tekstove u Moravskoj, a kasnije su preuzeti i u hrvatskoglagoljske rukopise, npr. mъnihъ, oplatъ, роръ

3. latinizmi uneseni nakon usklađivanja hrvatskoga prijevoda Biblije s Vulgatom od 12. stoljeća. Uz imena, to su većinom religijski i liturgijski termini, npr. Luciê, Ceceliê, šekvenciê, feriê, lekciê, lentiê, kalvariê, oštiê, vijiliê, šeksta, kapitulb, beršb, matutinb itd. Druge su riječi u manjem broju, npr. bumbakb, doktorb, dota, drakunb, dužb, lupunarb, moistrb, palma, polača, fistula, cêsarb itd.

U zbornicima je znatno veći broj romanizama iz govornoga jezika svakidašnjice, koji su se većinom unosili pod utjecajem predloška. Mnoge su novije posuđenice u glagoljske tekstove ušle iz latinskoga i talijanskoga, uglavnom iz venecijanskoga dijalekta ${ }^{89} \mathrm{Kad}$ je riječ o novijim posuđenicama (talijanizmima), katkad je teško

87 U primjere, koji se tvore prema kajkavskom modelu, ubrajaju se prilozi koji se tvore sufiksima: -uč, -ič, -oč, npr.: ednuč, drugoč, tretič, daleč itd. U hrvatskoglagoljskim je rukopisima već od 14. stoljeća potvrđen prilog drugočb i drugovičb: us'neši na stranê tvoei desnoi drugoč $\mathrm{BrVat}_{5}$ $232 \mathrm{c}$, drugovičb $\mathrm{BrVO} 455 \mathrm{c}$, otvêĉaše drugočb i rêše $\mathrm{BrN}_{2} 252 \mathrm{~d}$, i paki drugoč' ide i m(o)li

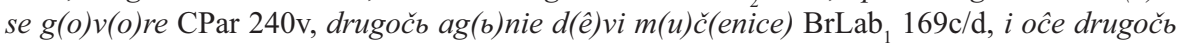
prosl(a)vlae MNov 70b, Tu peteh vspoe drugoč CTk 141r. Oblik je drugoč, drugač(e) hrvatsko-kajkavski, potvrđen u 17. i 18. stoljeću, ali ima ga i kod Marulića (SKOK 1971: 446). U hrvatskoglagoljskim se tekstovima pojavljuje i tretič, npr.: pride nikula têž'de naravomb s 'tvoreno tretičs is 'plniti želenie $\mathrm{BrN}_{2}$ 386a, p(o)m(i)lui n(a)sb tretič 'MVat ${ }_{4} 168 \mathrm{a}$, i pet' tretičb više poi an(tiponb) BrVO 29c. Vaspet tretič I(su)s tuci na vrata CTk 8 ), Tu Petar tretič zatai Isusa CTk $\left.141^{\mathrm{r}}\right)$.

U hrvatskoglagoljskim je zbornicima gdo (< kbto) znatno češći oblik od kto. I dok Z. Junković drži da se oblik gdo mogao razviti samo u kajkavskim govorima, S. Damjanović smatra da to opovrgavaju naši tekstovi u kojima supostoje kto i gdo. U biblijskim je tekstovima češće kto, a u ostalima $g d o$. „To bi onda dalje značilo da u slučaju te zamjenice uopće nemamo čakavski izraz, što je apsolutno isključeno za jedan zbornik u kojem je potka nesumnjivo čakavska. (CKz M. Š.) Uostalom, to bi bio jedini slučaj da za neki jezični sadržaj nemamo u našim tekstovima i čakavski izraz! Gdo je, smatramo, zajedničko dobro čakavštine i kajkavštine i ne možemo ga u našim tekstovima označiti kao kajkavizam. To potvrđuju i mnoge listine“ (DAMJANOVIĆ 1984: 163). 
posve pouzdano zaključiti kojim je putem neki leksem ušao u hrvatski jezik, je li to raguzejski, mletački ili toskanski. ${ }^{90} \mathrm{Od}$ starih romanizama u CIvan nalazimo neput, tj. naput, polača, kaštel, žežin.

Primjeri:

Mirakuli Marije Magdalene: s'panžatur'niceju $\left(113^{\mathrm{r}}\right)$, skuža $\left(113^{\mathrm{r}}\right)$, polaču $\left(115^{\mathrm{r}}\right)$, pelegrinb $\left(116^{\mathrm{v}}, 118^{\mathrm{r}}\right)$, monistri $\left(121^{\mathrm{r}}\right)$, manastira $\left(121^{\mathrm{r}}\right)$, iš toriê $\left(121^{\mathrm{v}}\right)$.

Različite molitve: moistar $\left(136^{v}\right)$, šerafimi $\left(137^{\vee}\right)$, polaču $\left(139^{\vee}\right)$.

Mirakuli Blažene Djevice Marije: mirakulb $\left(99^{\mathrm{v}}, 102^{\mathrm{r}}\right)$, polaču $\left(103^{\mathrm{r}}, 103^{\mathrm{v}}, 105^{\mathrm{r}}\right)$, punestricu $\left(103^{\mathrm{v}}\right)$, funestrici $\left(105^{\mathrm{r}}\right)$, pelegrinb $\left(111^{\mathrm{r}}\right)$.

Traktat o sedam smrtnih grijeha: superbie $\left(2^{\mathrm{r}}, 6^{\mathrm{r}}\right)$, ipokriziê $(3 \mathrm{v})$, ot nature $\left(4^{\mathrm{v}}\right)$, ot furtune $\left(4^{\mathrm{v}}\right)$, tem 'perancu $\left(4^{v}\right)$, tur'na $\left(7^{\mathrm{r}}\right)$, prsura $\left(8^{\mathrm{v}}\right)$, friti $\left(8^{\mathrm{v}}\right)$, od munite $\left(9^{\mathrm{v}}\right)$, munita $\left(11^{\mathrm{v}}\right)$, kaš'telb $\left(16^{\mathrm{r}}, 27^{\mathrm{r}}, 48^{\mathrm{r}}\right)$, opatie $\left(18^{\mathrm{r}}\right)$, skule $\left(22^{\mathrm{v}}\right)$, sakrilijì $\left(22^{\mathrm{v}}\right)$, šimuniê $\left(22^{\mathrm{v}}\right)$, bordêlb $\left(23^{\mathrm{r}}\right)$, taštamenti $\left(26^{\mathrm{v}}\right)$, al 'mužna $\left(26^{\mathrm{v}}\right)$, oštari $\left(27^{\mathrm{v}}\right)$, skuli $\left(28^{\mathrm{r}}\right)$, skulani $\left(28^{\mathrm{r}}\right)$, span'žanb $\left(29^{\mathrm{r}}\right)$, svoimb naputomb $\left(31^{\mathrm{r}}\right)$, matrimonii $\left(32^{\mathrm{r}}\right)$, kun'šencii $\left(33^{\mathrm{r}}\right)$,

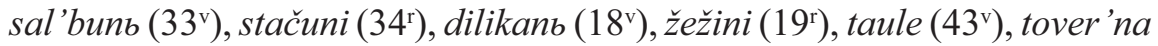
i tover'nar $\left(47^{\mathrm{v}}\right)$, bikarii $\left(56^{\mathrm{r}}\right)$, skalina $\left(57^{\mathrm{r}}\right)$ itd.

\section{Grecizmi}

U Traktatu, uz ostale leksičke slojeve, nalazimo i grecizme, npr.: cimiterb $\left(29^{v}\right)$, aerb $\left(49^{v}\right)$, apokalipass $\left(1^{\mathrm{r}}\right)$, dimunb $\left(44^{\mathrm{v}}\right)$, gamalions $\left(54^{\mathrm{r}}\right)$, mamona $\left(35^{\mathrm{v}}\right)$, koludra $\left(98^{v}\right)$, koludarb (99r), v'tem'palb $\left(100^{v}\right)$, koludrice $\left(109^{\vee}\right)$, parisêi $\left(113^{\mathrm{r}}\right)$, sa aramatami $\left(120^{v}\right)$, proz'vitera $\left(143^{\mathrm{r}}\right)$ itd.

\section{Zaključak}

Hrvatskoglagoljski su neliturgijski rukopisi pisani mješavinom staroslavenskih i starohrvatskih jezičnih elemenata. U odabiru jednih ili drugih karakterizira ih velika autorska sloboda, različita od kodeksa do kodeksa i od teksta do teksta. Svojom su se slobodom u izboru jezičnih sredstava prevoditelji, pisci i supisci Ivančićeva zbornika obilato koristili. Općenito možemo reći da je kodeks pisan mješavinom crkvenoslavenskoga i čakavskoga te da se tekstovi međusobno prilično razlikuju. Kajkavski je utjecaj zamjetan samo u Traktatu o sedam smrtnih grijeha, dok u ostalim dijelovima nailazimo samo na natruhe kajkavštine.

90 LOVRIĆ-JOVIĆ 2006: 177. 
Provedeno se istraživanje na leksičkoj razini uglavnom slaže s ranijim rezultatima: najarhaičniji je jezik u Poslanicama sv. Jeronima (pisane su crkvenoslavenskim jezikom), slijede ih Mirakuli Marije Magdalene (u leksiku dosta arhaičnosti), Molitve (nisu strogo liturgijski tekst, pa ima i narodnih osobina, leksik je prilično arhaičan), Čudesa Dive Marie (u leksiku prožimanje mlađih i starijih oblika), Traktat, Ishod i Ispovêd (imaju sličan jezik, gotovo potpuno se oslanjaju na govor, u leksiku je mnogo tuđica i mlađih oblika), Kontemplacion, Riči života i spaseniê (naslanja se na jezik Traktata, u leksiku su mnogi govorni elementi). Zadnjih je devet listova (f. 172 -181), odlomak koji je pisala druga ruka, pisano čakavskim, uz neke natruhe kajkavskoga. Blagoslov stola, u odnosu na spomenute tekstove, razlikuje se po tome što je to biblijski tekst preuzet iz nekih liturgijskih rukopisa, pa je pisan crkvenoslavenskim jezikom hrvatske redakcije.

Leksička je građa najraznolikija u Traktatu o sedam smrtnih grijeha. Temeljni je leksički sloj ovdje slavenski: uz starocrkvenoslavenske lekseme, nalazimo čakavske i kajkavske. U Traktatu znatno je više tuđica nego u drugim dijelovima: $\mathrm{i}$ to grecizama, romanizama (što je i razumljivo jer je taj tekst preveden negdje $u$ Italiji), germanizama i hungarizama. Kajkavizmi su u Traktatu dvovrsni: 1. oni koji se ubrajaju u zajedničko čakavsko-kajkavsko blago: hiniti, lotar, moistar, takaiše, praviti, hud, kaštigati, hiniti, mledn, tanaci, te 2. pravi kajkavizmi potvrđeni samo u sjevernim krajevima: špot, faita, hlap, prokšen. Prvi su znatno češći. Ako usporedimo dva ista teksta, Traktat u Ivančićevu i Kolunićevu zborniku, možemo zaključiti da je Ivančićev zbornik više čakavski obojen, za razliku od Kolunićeva, gdje su izrazitiji kajkavizmi.

Glagoljski tekstovi pisani hibridnim čakavsko-kajkavskim, a katkad i crkvenoslavenskim jezikom, ne pružaju neposredne podatke o vremenu i mjestu nastanka ili pisanja. To se donekle može odrediti poredbenim putem, tj. utvrđivanjem određenih analogija između pojedinih rukopisa, za koje su poznata mjesta pisanja. Za Ivančićev je zbornik već utvrđeno da je to zadarsko područje, dok bi predložak Traktata, prema jezičnim obilježjima, pripadao sjevernijim krajevima.

Važno je detaljno opisati svaki kodeks na svim jezičnim razinama, pa tako i na leksičkoj, jer je bogata leksička građa hrvatskoglagoljskih zborničkih tekstova značajan korak u uređivanju književnoga jezika, tj. hrvatskoga standarda. 


\section{Prilog}

U prilogu navodim neke rečenice u kojima dolazi do izražaja prevoditeljska kreativnost i smisao za humor, kao i jezično bogatstvo hrvatskoglagoljskih zborničkih tekstova:

Taĉa sl(a)va e(stb) veliki viharb koga d'êv(a)lb rene s velikovb tučuvb ki meĉe na z(e)mlju veliko s'tab'lie po dubravahb i podira cere i dubi veliki $\left(9^{r}\right)$;

gos 'poê lipa urišen'a e(stb) vece pag(u)b'na nego strêla bališ trena vo onoga Are nima uda ni urêšen'ê na sebi v' koi bi ne bilo m'rêže ili zam 'č'ice d'êvle za lovl(e)nie $\left(37^{\mathrm{r}}\right)$;

O grêhu grla (proždrljivosti): Mnogo e mr'zakb b(og)u sa gr(ê)hb are vsaki č(lovê)kb žr 'tvenikb čini s'voga b(og)a da čl(ovê)kb čini svoga b(og)a v'ed'noi vriĉi plni g'noê i da se č(lovê) kb boi veĉe svoga č' rêva i ljubi nego b(og)a b(og)b $z(a) p(o) v(\hat{e}) d a$ žežinb i v'zdržanie a črêvo z(a)p(o)v(ê) da da č (lovê) kb ji dovole $i$ kohato b(og) z zap(o)v(ê)da na jutr'nju v'stati a črêvo di veliko samb pl'no s'pati mi e potrêb'no skrozi bole moju kr'mu probaviti A paki kada se vstane nikada kas'no prie nego reče svoe m(o)l(it)ve ili svoju jutr'nju zač'ne mislitio svoemb č 'rêvi I I pita ča bis 'mo d(a)n(a)ska imili jis 'ti bismo li mogli ča slat'ko naiti d(o)bro biše vino sinoĉ 'ne bis'mo li mogli takoiše naiti ili bol'še (41');

Kada č(lovê)kb žr 'tacb grede v' tover'nu onb grede lipo pravo a kada se vraĉa ne more se dr'žati na svoihb nogahb i e(stb) eki (!) pogubilb vidb i sluhb ričb $i$ umb i računb i pamets $\left(48^{\mathrm{r}}\right)$;

Niki êz(i)ci su ki su t(a)ko pl'ni vitra da govore vitru i aeru ki ne mogu edan' časb ml(b)čati k(a)ko klepacb malinni a ono ča govore nima gl(a)ve ni računa (49v);

Mnogo e(stb) težakb grêhb i grubb i s'ramotan' onoga ki se hv(a)li $\cdot T(a) k o v i$ ričivacb e(stb) tat'b(o)ži ki mu krade nega sl(a)vu (50r);

$\check{C}($ lovê)kb lažacb e(stb) meju č(lovê) ci d(o)brimi t(a)ko k(a)ko krivi pinezb meju $d\left(\right.$ o) brimi ili k(a)ko slama va p̌s (e)nici $\left(53^{\mathrm{v}}-54^{\mathrm{r}}\right)$;

$S$ (ve)ti avgustino pravi da nič' ce ni toliko prikladno činomb d'êvlimb koliko e(stb) karati se otkuda sa gr(ê)hb e(stb) ugodanb d'êvlu a mr'zak'b(og)u ki ljubi mirb $i$ skladb $\left(57^{\mathrm{r}}\right)$

Zato e(stb) vsa m(u)dr(o)stb sega svita ludostb I oni ki m'ne vidjeti ne vide ni mr've. Oni diju da imaju oči i da vide A čb veĉe vidê mane se znaju. Vs(a)ki $d($ a)nb um'ru a ne umiju umriti ni s'miju are se nisu naučili d(o)bro živiti (63'); Konb vs(a)ke s(ve) te d(u)še e(stb) t(ê)lo ko ima ona stisnuti ot vs(i)hb zlihb pohoti uzdovb v'zdržaniê a pustiti ostrogami ljubve ganutiem' dobrihb dêlb $\left(78^{v}\right)$;

I ôce imate viditi da edanb gr(ê) hb priteže drugoga $\left(83^{v}\right)$. 
Kratice hrvatskoglagoljskih rukopisa

BrAc - Akademijin brevijar, oko 1384., Zagreb, Hrvatska akademija znanosti i umjetnosti, sign. III c 12.

BrBar - Baromićev brevijar, 1493. (tiskan), Mleci (Venecija).

$\mathrm{BrN}_{2}-$ II. novljanski brevijar, 1495., Novi Vinodolski, Župni ured.

BrPm - Pašmanski brevijar, druga polovina 14. i 15. stoljeća, Zagreb, Hrvatska akademija znanosti i umjetnosti, sign. III b 10.

$\mathrm{BrVat}_{5}-$ V. vatikanski brevijar, sredina 14. stoljeća, Biblioteca Apostolica Vaticana, sign. Borg illir. 5.

BrVat $_{6}$ - VI. vatikanski brevijar, sredina 14. stoljeća, Biblioteca Apostolica Vaticana, sign. Borg illir. 6.

$\mathrm{BrVb}_{4}-I V$. vrbnički brevijar, 14. stoljeće, Vrbnik, Župni ured.

BrVO - Brevijar Vida Omišljanina, 1396., Beč, Österreichische Nationalbibliothek, sign. Cod. slav. 3.

CAc - Zbornik duhovnog štiva (Antoninov konfesional i dr.), kraj 15. stoljeća, Zagreb, Hrvatska akademija znanosti i umjetnosti, sign. IV a 48.

CIvan - Ivančićev zbornik, 14. - 15. stoljeće, Zagreb, Samostan franjevaca III. reda.

$\mathrm{CKz}$ - Kolunićev zbornik, 1486; Zagreb, Hrvatska akademija znanosti i umjetnosti, sign. III a 51 .

COxf-Oxfordski zbornik, 15. stoljeće, Oxford, Bodleian Library, sign. Ms. Canon. Lit. 414.

CTk - Tkonski zbornik, prva četvrtina 16. stoljeća, Zagreb, Hrvatska akademija znanosti i umjetnosti, sign. IV a 120.

FgLab - Ljubljanski homilijar, 13. stoljeće, Ljubljana, Narodna in univerzitetna knjižnica, Slavische Sammlung, fut. 5, br. 368.

Mber - Berlinski misal, 1402., Berlin, Staatsbibliothek zu Berlin, sign. Ms. Ham. 444.

MHrv - Hrvojev misal, oko 1404., Carigrad, Topkapi Sarayi.

$\mathrm{MLab}_{2}$ - II. ljubljanski (beramski) misal, 15. stoljeće, Ljubljana, Narodna in univerzitetna knjižnica, sign. Ms 164 (stara sign. C 164a/2).

MNew - Newyorški misal, sredina 15. stoljeća, New York, The Pierpont Morgan Library, sign. M. 931.

MOxf $_{1}$-I. oxfordski misal, 15. stoljeće, Oxford, Bodleian Library, sign. Ms. Canon. Lit. 373.

MOxf $_{2}$-II. oxfordski misal, 15. stoljeće, Oxford, Bodleian Library, sign. Ms. Canon. Lit. 349.

MVat $_{8}$ - VIII. Vatikanski misal, 1435., Rim, Biblioteca Apostolica Vaticana, sign. Borg. illir. 8.

$\mathrm{MVb}_{1}-$ I. vrbnički misal, 1456., Vrbnik, Župni ured.

RegBen - Regula sv. Benedikta, kraj 14. stoljeća, Zagreb, Hrvatska akademija znanosti i umjetnosti, sign. I a 74.

TIZ - Traktat Ivančićeva zbornika.

TKZ - Traktat Kolunićeva zbornika. 


\section{Bibliografija}

AR. 1880-1976. Rječnik hrvatskoga ili srpskoga jezika. Zagreb: Jugoslavenska akademija znanosti i umjetnosti.

ARj III. 1887-1891. Rječnik hrvatskoga ili srpskoga jezika. Dio III (Đavo - Isprekrajati). Ur. Pero Budmani. Zagreb: Jugoslavenska akademija znanosti i umjetnosti.

BORYŚ, Wiesław. 2007. Čakavske leksičke studije. Praslavensko naslijeđe u čakavskome leksičkom fondu. Zagreb: Matica hrvatska.

DAMJANOVIĆ, Stjepan. 1984. Tragom jezika hrvatskih glagoljaša. Zagreb: Hrvatsko filološko društvo.

DAMJANOVIĆ, Stjepan. 2008. Jezik hrvatskih glagoljaša. Zagreb: Matica hrvatska.

DAMJANOVIĆ, Stjepan. 2009. Staroslavenski i starohrvatski u hrvatskim srednjovjekovnim tekstovima. U Povijest hrvatskoga jezika. 1. knjiga: Srednji vijek, ur. Ante Bičanić, 351-403. Zagreb: Društvo za promicanje hrvatske kulture i znanosti Croatica.

DAMJANOVIĆ, Stjepan. 2011. Jezik hrvatskih glagoljičnih tekstova. U Povijest hrvatskoga jezika. 2. knjiga: 16. stoljeće, ur. Ante Bičanić, 275-321. Zagreb: Društvo za promicanje hrvatske kulture i znanosti Croatica.

DAMJANOVIĆ, Stjepan. 2014. Novi filološki prinosi. Zagreb: Matica hrvatska.

DIMITROVA, Margaret. 1998. Greek and Latin Loanwords and Names in Croatian Glagolitic Missals. PhD disertation. Budapest: Central European University.

FANCEV, Franjo. 1925. O najstarijem bogoslužju u Posavskoj Hrvatskoj. U Zbornik kralja Tomislava u spomen tisućugodišnjice hrvatskoga kraljevstva [Posebna djela, knj. 17], 509-553. Zagreb: Jugoslavenska akademija znanosti i umjetnosti.

FUČIĆ, Branko. 1982. Glagoljski natpisi [Djela Jugoslavenske akademije znanosti i umjetnosti, knj. 57]. Zagreb: Jugoslavenska akademija znanosti i umjetnosti.

GAČIĆ, Jasna. 1979. Romanski elementi u splitskom čakavskom govoru. Čakavska rič 9/1: 3-54.

GRABAR, Biserka. 1984. Tiskani glagoljski Baromićev brevijar. Slovo 34: 159-180.

HERCIGONJA, Eduard. 1975. Povijest hrvatske književnosti. Knjiga 2. Zagreb: Liber.

HERCIGONJA, Eduard. 1983. Kajkavski elementi u jeziku glagoljaške književnosti 15. i 16. stoljeća. U Nad iskonom hrvatske knjige, 303-385. Zagreb: Sveučilišna naklada Liber.

JAGIĆ, Vatroslav. 1914. Zur Visio Tundali. Archiv für slavische Philologie 35: 501-513.

JAPUNDŽIĆ, Marko. 1955. Glagoljski brevijar iz g. 1465. Radovi Staroslavenskog instituta 2: 155-192.

KOLENDIĆ, Petar. 1935. Somme le Roi kod naših glagoljaša. Južni pregled IX: 396-400.

KOSIĆ, Ivan. 2010. Ivančićev zbornik, hrvatskoglagoljski neliturgijski rukopis iz XIV./ $X V$. st. Doktorska disertacija. Zagreb: Sveučilište u Zagrebu Filozofskoga fakulteta.

LISAC, Josip. 2009. Hrvatska dijalektologija 2. Čakavsko narječje. Zagreb: Golden marketing, Tehnička knjiga.

LOVRIĆ-JOVIĆ, Irena. 2006. Fonološka adaptacija talijanizama u dubrovačkim oporukama 17. i 18. st. Rasprave Instituta za hrvatski jezik i jezikoslovlje 32: 173-192. 
KUZMIĆ, Boris. 2001. Jezik Veprinačkog zakona (1507). Fluminensia - časopis za filološka istraživanja Rijeka 13/1-2: 1-24.

MARESIĆ, Jela. 2006. O slavonsko-kajkavskoj leksičkoj isprepletenosti. Riječ 1/12: 31-36.

MARTI, Roland. 1994. Problemi na značenieto na slavjanskata leksika ot kirilo-metodievsko vreme. Palaeobulgarica/Starobъlgaristika XVIII/4: 23-39.

MIHALJEVIĆ, Milan. 1997. Jezična slojevitost Brevijara Vida Omišljanina iz 1396. godine. Filologija 29: 119-138.

MIHALJEVIĆ, Milan. 2000. Dosadašnja čitanja darovnice slavnoga Dragoslava. Fluminensia - časopis za filološka istraživanja Rijeka. 12/1-2: 1-15.

MILČETIĆ, Ivan. 1890. Prilozi za literaturu hrvatskih glagolskih spomenika. Starine JAZU XXIII: 39-153.

MOGUŠ, Milan. 1977. Čakavsko narječje. Fonologija. Zagreb: Školska knjiga.

NAZOR, Anica. 1963. Jezični kriteriji pri određivanju donje granice crkvenoslavenskog jezika u hrvatskoglagoljskim tekstovima. Slovo 13: 68-86.

NAZOR, Anica. 1973. Karakteristike jezika i pisma Hrvojeva misala. U Missale Hervoiae ducis spalatensis croatico-glagoliticum. Transcriptio et commentarium, Editionem curaverunt B. Grabar, A. Nazor, M. Pantelić sub redactione V. Štefanić. Zagreb-Ljubljana-Graz: Staroslavenski institut Svetozar Ritig, Mladinska knjiga, Akademische Druck- und Verlagsanstalt.

PANTELIĆ, Marija. 1964. Glagoljski kodeksi Bartola Krbavca. Radovi Staroslavenskoga instituta 5: 5-98.

PANTELIĆ, Marija, Anica NAZOR. 1977. II. novljanski brevijar. Hrvatskoglagoljski rukopis iz 1495. Župni arhiv Novi Vinodolski. Fototipsko izdanje, Uvod - Bibliografija. Zagreb: Staroslavenski institut Svetozar Ritig, Turistkomerc.

PETROVIĆ, Ivanka. 1972. Bogorodičina čudesa u Ivančićevu zborniku, hrvatskoglagoljskom spomeniku 14/15. st. Radovi Staroslavenskog instituta 7: 123-210.

REINHART, Johannes. 1990. Altkroatisch tanac „Tanz“. Wiener slavistisches Jahrbuch VIII: 201-203.

REINHART, Johannes. 1996. Kroatisch und serbisch majstor, meštar, mojstar. Wiener slavistisches Jahrbuch 42: 161-172.

RIBAROVA, Zdenka. 2005. Jazikot na makedonskite crkovnoslovenski tekstovi. Skopje: Makedonska akademija na naukite i umetnostite.

Rječnik crkvenoslavenskoga jezika hrvatske redakcije. 2000. I. svezak (A - vrêdb). Gl. ur. B. Grabar, Z. Hauptová, F. V. Mareš. Zagreb: Staroslavenski institut.

RUNJE, Petar. 2008. Senjski kulturni krug i senjska tiskara. Senjski zbornik 35: 91-114.

RUNJE, Petar. 2012. Prema izvorima II. Rasprave i članci o hrvatskim franjevcima trećoredcima glagoljašima, ur. Tomislav Galović [Novaja i vethaja 9; Krčki zbornik 68, Posebno izdanje 61]. Krk-Zagreb: Povijesno društvo otoka Krka, Provincijalat franjevaca trećoredaca glagoljaša.

SAMARDŽIJA, Marko. 2011. Hrvatski leksik i leksikografija. U Povijest hrvatskoga jezika. 2. knjiga: 16. stoljeće, ur. Ante Bičanić, 441-459. Zagreb: Društvo za promicanje hrvatske kulture i znanosti Croatica. 
SKOK, Petar. Etimologijski rječnik hrvatskoga ili srpskoga jezika. 1971 - 1973. Knjiga $1(\mathrm{~A}-\mathrm{J}), 2$ (K - poni) 3 (poni - Ž). Zagreb: Jugoslavenska akademija znanosti i umjetnosti.

STOLAC, Dijana. 2011. Kajkavski hrvatski književni jezik. U Povijest hrvatskoga jezika. 2. knjiga: 16. stoljeće, ur. Ante Bičanić, 189-227. Zagreb: Društvo za promicanje hrvatske kulture i znanosti Croatica.

ŠIMIĆ, Marinka. 2005. Leksik Traktata o sedam smrtnih grijeha u Ivančićevu i Kolunićevu zborniku. U Drugi Hercigonjin zbornik, ur. Stjepan Damjanović, 397-410. Zagreb: Hrvatska sveučilišna naklada.

ŠIMIĆ, Marinka. 2011. Kajkavski utjecaj u 2. novljanskome brevijaru. U Az grišni diak Branko pridivkom Fučić. Radovi međunarodnoga znanstvenog skupa o životu i djelu akademika Branka Fučića (1920.-1999.), Malinska, Dubašnica, otok Krk (30. siječnja - 1. veljače 2009.), ur. Tomislav Galović, 501-520. Malinska-Rijeka-Zagreb: Hrvatska akademija znanosti i umjetnosti, Institut za povijest umjetnosti, Katolički bogoslovni fakultet Sveučilišta u Zagrebu, Staroslavenski institut, Sveučilišna knjižnica Rijeka, Općina Malinska Dubašnica.

ŠIMIĆ, Marinka. 2014. Akademijin brevijar. HAZU III c 12. Hrvatskoglagoljski rukopis s konca 14. stoljeća. Jezična studija, Transliteracija, Faksimil. Zagreb: Staroslavenski institut [Biblioteka Spomenici, knj. 1].

ŠTEBIH, Barbara. 2006. Transmorfemizacija imeničkih germanizama u kajkavskome književnom jeziku. Rasprave Instituta za hrvatski jezik i jezikoslovlje 32: 295-310.

ŠTEFANIĆ, Vjekoslav. 1960. Glagoljski rukopisi otoka Krka [Djela JAZU 51]. Zagreb: Jugoslavenska akademija znanosti i umjetnosti.

ŠTEFANIĆ, Vjekoslav. 1964. Glagoljski Transit svetog Jeronima u starijem prijevodu. Radovi Staroslavenskog instituta 5: 99-161.

ŠTEFANIĆ, Vjekoslav. 1969. Glagoljski rukopisi Jugoslavenske akademije. (I. dio-uvod, Biblija, apokrifi i legende, liturgijski tekstovi, egzorcizmi i zapisi, molitvenici, teologija, crkveni govori /homiletika/, pjesme). Zagreb: Historijski institut Jugoslavenske akademije znanosti i umjetnosti.

ŠTEFANIĆ, Vjekoslav. 1970. Glagoljski rukopisi Jugoslavenske akademije. (II. dio zbornici različitog sadržaja, regule i statuti, registri, varia, indeksi, album slika). Zagreb: Historijski institut Jugoslavenske akademije znanosti i umjetnosti.

TANDARIĆ, Josip. 1978. Glagoljaški ritual. Doktorska disertacija. Zagreb: Filozofski fakultet Sveučilišta u Zagrebu.

TANDARIĆ, Josip. 1980. Hrvatskoglagoljski ritual. Slovo 30: 17-87.

TANDARIĆ, Josip Leonard. 1993. Franjevački element u hrvatskoglagoljskim liturgijskim knjigama. U Hrvatsko glagoljska liturgijska književnost. Rasprave i prinosi, ur. Petar Bašić, 36-40. Zagreb: Kršćanska sadašnjost, Provincijalat franjevaca trećoredaca.

VALJAVAC, Matija. 1892. Kolunićev zbornik, hrvatski glagolski rukopis od godine 1486. [Djela JAZU, knj. XII.]. Latinicom na svijet izdala Jugoslavenska akademija znanosti i umjetnosti u Zagrebu. 
VEGO, Marko. Zbornik srednjovjekovnih natpisa Bosne i Hercegovine. 1962 - 1970. Knjiga I - IV. Sarajevo: Zemaljski muzej.

VONČINA, Josip. 1988. Jezična baština. Lingvostilistička hrestomatija hrvatske književnosti od kraja 15. do početka 19. stoljeća. Split: Književni krug.

\section{Lexis of the Ivančić's Collectaneum}

The vocabulary of the Croatian Glagolitic manuscripts is multi-layered, especially of the non-liturgical texts in collective manuscripts in which Cakavica/ Kajkavica elements are brought into the Church Slavonic basis in order to shape a literary language understandable in the widest possible area. The share of this component differs from text to text, even in the same manuscript. The Collectaneum of Ivancić is a Glagolitic manuscript of the $14^{\text {th }} / 15^{\text {th }}$ century containing diverse religious-moral writings, named after and found by the Franciscan Stjepan Ivančić in the Franciscan monastery of Glavotok on the island of Krk, kept today in the Franciscan monastery on the Ksaver hill in Zagreb. Linguistic studies have shown the manuscript's language to be pretty unhomogenous, i. e. in some parts it is rather Church Slavonic, in other parts on the other hand rather vernacular. This applies to all language levels. The present paper examines the vocabulary of the Ivancić's Collectaneum seeking to answer the question of the ratio between the Church Slavonic and vernacular idioms in single texts. Special attention will be directed to the relationship to the adoption of Kajkavica lexems, i. e. whether they are distributed equally in all parts of the manuscript.

Keywords: Croatian Glagolitic Manuscripts, Ivančić's Collectaneum, lexis, Čakavisms, Kajkavisms

Ključne riječi: hrvatskoglagoljski rukopisi, Ivančićev zbornik, leksik, čakavizmi, kajkavizmi

Marinka Šimić Staroslavenski institut HR-10000 Zagreb, Demetrova 11 msimic@stin.hr 


\section{FILOZOFSKI FAKULTET SVEUČILIŠTA U ZAGREBU \\ ZAVOD ZA HRVATSKU POVIJEST \\ INSTITUTE OF CROATIAN HISTORY \\ INSTITUT FÜR KROATISCHE GESCHICHTE}


ZAVOD ZA HRVATSKU POVIJEST

FILOZOFSKOGA FAKULTETA SVEUČILIŠTA U ZAGREBU

\section{PF press \\ ZAGREB 2015.}




\title{
RADOVI ZAVODA ZA HRVATSKU POVIJEST FILOZOFSKOGA FAKULTETA SVEUČILIŠTA U ZAGREBU
}

\author{
Knjiga 47, vol. 1
}

\author{
Izdavač / Publisher \\ Zavod za hrvatsku povijest \\ Filozofskoga fakulteta Sveučilišta u Zagrebu \\ FF-press \\ Za izdavača / For Publisher \\ Vlatko Previšić \\ Glavni urednik / Editor-in-Chief \\ Hrvoje Gračanin \\ Izvršna urednica / Executive Editor \\ Inga Vilogorac Brčić \\ Uredništvo / Editorial Board
}

Bruna Kuntić-Makvić (stara povijest/ancient history), Zrinka Nikolić Jakus (srednji vijek/ medieval history), Hrvoje Petrić (rani novi vijek/early modern history), Željko Holjevac (moderna povijest/modern history), Tvrtko Jakovina (suvremena povijest/contemporary history),

Silvija Pisk (mikrohistorija i zavičajna povijest/microhistory and local history),

Zrinka Blažević (teorija i metodologija povijesti/theory and methodology of history)

Međunarodno uredničko vijeće / International Editorial Council

Denis Alimov (Sankt Peterburg), Živko Andrijašević (Nikšić), Csaba Békés (Budapest), Rajko Bratož (Ljubljana), Snježana Buzov (Columbus, Ohio), Svetlozar Eldarov (Sofija), Toni Filiposki (Skopje), Aleksandar Fotić (Beograd), Vladan Gavrilović (Novi Sad), Alojz Ivanišević (Wien),

Egidio Ivetić (Padova), Husnija Kamberović (Sarajevo), Karl Kaser (Graz),

Irina Ognyanova (Sofija), Géza Pálffy (Budapest), Ioan-Aurel Pop (Cluj),

Nade Proeva (Skopje), Alexios Savvides (Kalamata), Vlada Stanković (Beograd), Ludwig Steindorff (Kiel), Peter Štih (Ljubljana)

Izvršna urednica za tuzemnu i inozemnu razmjenu / Executive Editor for Publications Exchange Kristina Milković

Tajnik uredništva / Editorial Board Assistant

Dejan Zadro

Adresa uredništva/Editorial Board address

Zavod za hrvatsku povijest, Filozofski fakultet Zagreb, Ivana Lučića 3, HR-10 000, Zagreb

Tel. ++385 (0)1 6120 150, 6120 158, faks ++385 (0)1 6156879

Časopis izlazi jedanput godišnje / The Journal is published once a year

Časopis je u digitalnom obliku dostupan na / The Journal in digital form is accessible at Portal znanstvenih časopisa Republike Hrvatske „Hrčak“ http://hrcak.srce.hr/radovi-zhp

Financijska potpora za tisak časopisa / The Journal is published with the support by

Ministarstvo znanosti, obrazovanja i športa Republike Hrvatske

Časopis je indeksiran u sljedećim bazama / The Journal is indexed in the following databases:

Directory of Open Access Journals, EBSCO, SCOPUS, ERIH PLUS 
Naslovna stranica

Iva Mandić

Grafičko oblikovanje i računalni slog

Marko Maraković

Lektura

Samanta Paronić

Tisak

Web2tisak, Zagreb

Naklada

250 primjeraka

Časopis je u digitalnom obliku dostupan na Portalu znanstvenih časopisa Republike Hrvatske ,Hrčak“ http://hrcak.srce.hr/radovi-zhp

The Journal is accessible in digital form at the Hrcak - Portal of scientific journals of Croatia http://hrcak.srce.hr/radovi-zhp 


\section{RADOVI 47}

\section{vol. 1}

ZaVoda za hrVAtSku poviJest FILOZOFskoga fakulteta SVeuČILIŠTA u Zagrebu 


\title{
Tematski blok / Themed issue
}

\section{TREĆOREDSKA GLAGOLJAŠKA TRADICIJA U EUROPSKOM KONTEKSTU TERTIARY GLAGOLITIC TRADITION IN EUROPEAN CONTEXT}

\author{
Radovi međunarodnoga znanstvenog skupa \\ održanoga 27. i 28. IX. 2013. na Hrvatskom katoličkom sveučilištu u Zagrebu \\ u organizaciji \\ Provincije franjevaca trećoredaca glagoljaša u Zagrebu, Hrvatskoga katoličkog \\ sveučilišta u Zagrebu, Filozofskoga fakulteta Sveučilišta u Zagrebu - Odsjek za \\ povijest, Filozofskoga fakulteta Sveučilišta u Splitu - Odsjek za povijest, Instituta \\ za povijest umjetnosti u Zagrebu i Staroslavenskoga instituta u Zagrebu \\ Proceedings of the International Scientific Conference \\ held on 27th and 28th September 2013 at the Catholic University of Croatia in Zagreb \\ and organized by \\ the Province of the Glagolitic Friars of the Third Order Regular, Catholic University \\ of Croatia in Zagreb, Faculty of Humanities and Social Sciences of the University \\ of Zagreb - Department of History, Faculty of Humanities and Social Sciences of \\ the University of Split - Department of History, Institute of Art History, \\ and Old Church Slavonic Institute
}

Gosti urednici / Guest editors

\author{
Ivan BOTICA \\ Tomislav GALOVIĆ \\ Kristijan KUHAR
}

